\title{
Synthesis of stereodefined piperidines from aziridines and their transformation into conformationally constrained amino acids, amino alcohols and 2,7-diazabicyclo[3.3.1]nonanes
}

\author{
Karel Vervisch, ${ }^{a}$ Matthias D’hooghe, ${ }^{a}$ Karl W. Törnroos ${ }^{b}$ and Norbert De Kimpe* ${ }^{* a}$ \\ ${ }^{a}$ Department of Organic Chemistry, Faculty of Bioscience Engineering, Ghent University, \\ Coupure Links 653, B-9000 Ghent, Belgium \\ ${ }^{b}$ Department of Chemistry, University of Bergen, Allégt 41, 5007 Bergen, Norway
}

norbert.dekimpe@UGent.be

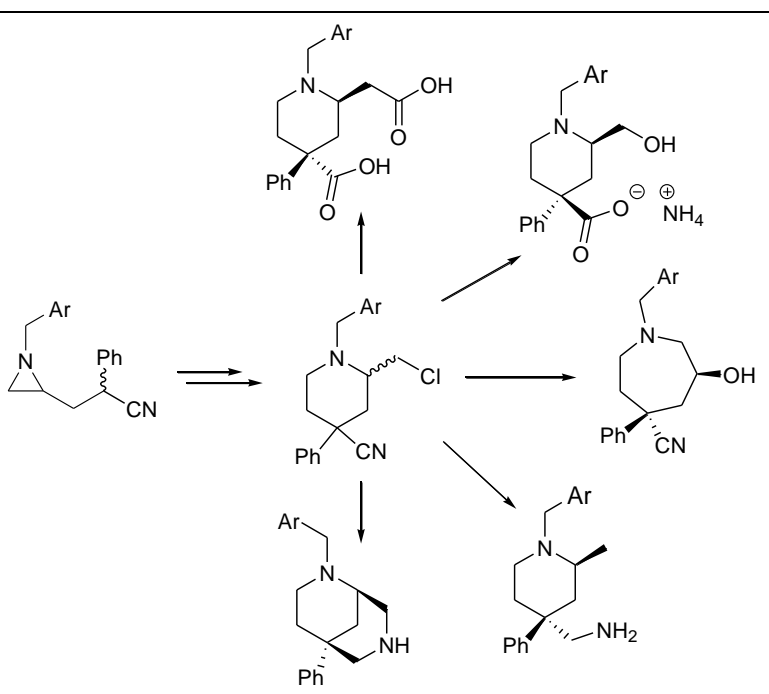

2-(2-Cyano-2-phenylethyl)aziridines were converted into novel cis- and trans-2-chloromethyl-4phenylpiperidine-4-carbonitriles via alkylation with 1 bromo-2-chloroethane followed by microwaveassisted 6-exo-tet cyclisation and regiospecific ring opening. The latter piperidines were used as eligible substrates for the synthesis of stereodefined 2-chloromethyl-, 2-hydroxymethyl- and 2carboxymethyl-4-phenylpiperidine-4-carboxylic acids, 2-hydroxymethyl-4-phenylpiperidine-4- 
carbonitriles,

diazabicyclo[3.3.1]nonanes.

\section{Introduction}

The piperidine ring comprises an important structural unit in natural products and biologically active agents, and several thousands of piperidine compounds have been evaluated in clinical and preclinical studies. ${ }^{1}$ For these reasons, the search for general, efficient and stereoselective methods for piperidine synthesis has attracted the attention of the organic chemistry community for many years. $^{2}$ In particular, 4-arylpiperidines represent an interesting class of biologically relevant compounds, about which numerous examples can be found in the patent literature. ${ }^{3}$ 4Arylpiperidines are known to be useful as for example tachykinin antagonists for the treatment of pain and inflammation, ${ }^{4}$ and as $\alpha-1$ a adrenergic receptor antagonists for the treatment of prostate disorders. ${ }^{5}$ Moreover, a number of drugs accommodate a 4-arylpiperidine unit in their structure, such as the analgesic meperidine $\mathbf{1}$ and the antipsychotic haloperidol $2 .^{6}$

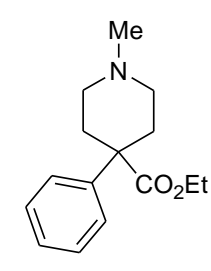

Meperidine 1

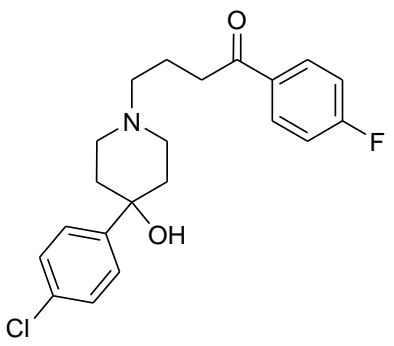

Haloperidol 2

From a synthetic point of view, aziridines have proven to be excellent precursors for the preparation of functionalized piperidines. Indeed, intramolecular ring opening of aziridines by a remote amino moiety, ${ }^{7}$ and ring opening using Grignard reagents followed by elaboration of the tethered side chain $^{8}$ are known strategies for the synthesis of piperidines starting from aziridines. Alternatively, [3+3]-cycloadditions of Pd-trimethylenemethane complexes with enantiomerically pure aziridines, ${ }^{9}$ and aza-[2,3]-wittig rearrangements of vinylaziridines ${ }^{10}$ have also been used successfully in that respect. 
In this paper, an efficient and direct method toward the novel 2-chloromethyl-4-phenylpiperidine-4carbonitrile scaffold is presented starting from 2-(2-cyano-2-phenylethyl)aziridines. Piperidine-4carbonitriles were employed successfully as substrates for the synthesis of a wide variety of stereodefined piperidines ranging from $\gamma$-amino acids and adipic acid derivatives to bicyclic piperidines with biological interest.

\section{Results and discussion}

The chemistry of 2-(2-cyanoethyl)aziridines remains an underexplored field of research, as only a few examples have been reported so far. $^{11}$ Nevertheless, their synthetic usefulness has been demonstrated recently through the development of a versatile aziridine to cyclopropane ring transformation. ${ }^{12}$ In continuation of our interest in 2-(cyanoalkyl)aziridines ${ }^{12,13}$ as substrates in organic chemistry, a new protocol for the conversion of 2-(2-cyanoethyl)aziridines into functionalized piperidines was developed.

1-Arylmethyl-2-(bromomethyl)aziridines 4, prepared from the corresponding benzaldehydes in a three-step procedure, ${ }^{14}$ are known to be excellent substrates for the synthesis of a variety of 2substituted 1-(arylmethyl)aziridines. ${ }^{12,15}$ Thus, 2-(bromomethyl)aziridines 4 were treated with 1.1 equiv of $\alpha$-lithiated phenylacetonitrile in THF, affording 2-(2-cyano-2-phenylethyl)aziridines $\mathbf{5}$ as mixtures of diastereomers in good yields. ${ }^{12 b}$ With the intention to introduce a 2-chloroethyl group in $\alpha$-position with respect to the nitrile moiety in aziridines 5 , the coupling between 1-bromo-2chloroethane and aminonitriles $\mathbf{5}$ was accomplished using 1.2 equiv of lithium diisopropylamide (LDA) in THF, furnishing novel 4-chloro-2-[1-(arylmethyl)aziridin-2-ylmethyl]-2-phenylbutyronitriles 6 and 7 as a mixture of diastereomers $(1 / 1)$ after one hour at $0^{\circ} \mathrm{C}$ (Scheme 1$)$. Interestingly, diastereomers 6 could be easily isolated from the mixtures by crystallization from ethanol (15-40\% yield), and diastereomers 7 were obtained in pure form through column chromatography on silica gel (hexane/EtOAc 3/1, 15-35\% yield), allowing their full spectroscopic characterization. 


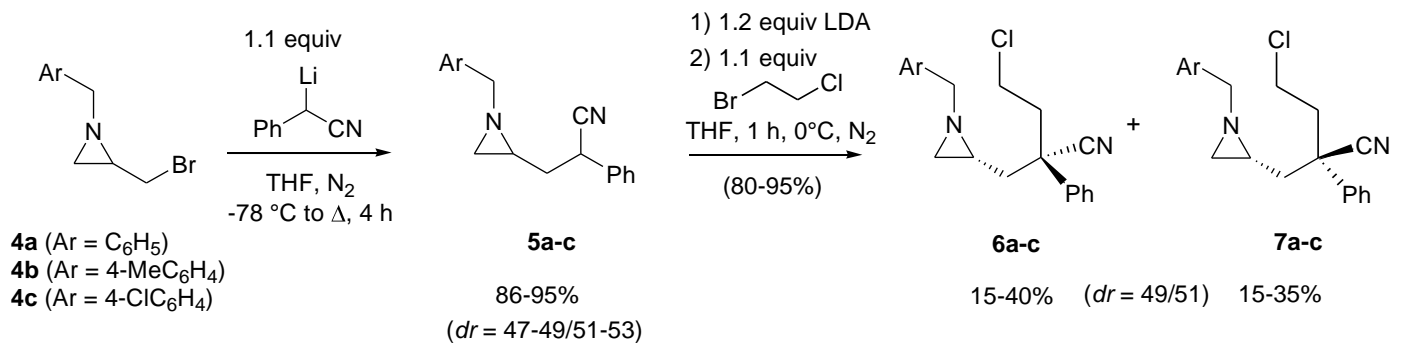

The incorporation of a leaving group in $\varepsilon$-position with regard to the aziridine nitrogen atom renders aziridines 6 and 7 excellent substrates for a 6-exo-tet ring closure toward intermediate bicyclic aziridinium salts, suitable for further elaboration. It should be noted that the $\alpha$-alkylation of nitriles using 2-chloro-1-haloethanes has been reported scarcely in the literature. ${ }^{16}$

Interestingly, when heated under reflux in THF, no cyclisation of aziridines $\mathbf{6}$ and $\mathbf{7}$ toward piperidines took place. Clearly, a more polar solvent had to be used to allow intramolecular substitution and stabilize the intermediate bicyclic aziridinium ions. In accordance with the previously reported ring opening reactions of non-activated aziridines with benzyl bromide, ${ }^{12,15 d, 17}$ acetonitrile was used as a solvent, and the premised 6-exo-tet ring expansion reaction of aziridines 6 and 7 proceeded nicely under microwave irradiation at $136^{\circ} \mathrm{C}$ for 30 minutes or, alternatively, in DMSO for 3 hours under reflux applying conventional heating, affording 2-chloromethyl-4-phenylpiperidine-4-carbonitriles 9 and 11 in excellent yields and purity (Scheme 2). The proposed mechanism involves an intramolecular substitution reaction, furnishing bicyclic aziridinium intermediates 8 and $\mathbf{1 0}$, followed by regiospecific ring opening by chloride at the less hindered aziridine carbon atom toward 2chloromethyl-4-phenylpiperidine-4-carbonitriles $\mathbf{9}$ and $\mathbf{1 1 .}$

Alternatively, trans-piperidines $\mathbf{1 1}$ were isolated more easily performing the 6-exo-tet ring expansion reaction on the diastereomeric mixture of aziridines 6 and 7, as trans-piperidines 11 could be crystallized from the reaction mixture using ethanol as a solvent [40-43\% of piperidines $\mathbf{1 1}$ starting from 2-(2-cyano-2-phenylethyl)aziridines 5]. The relative stereochemistry of trans-2-chloromethyl-4- 
phenylpiperidine-4-carbonitriles $\mathbf{1 1}$ was unambiguously assigned by X-ray crystallographic analysis of piperidine 11b (See Supporting information).

\section{SCHEME 2}
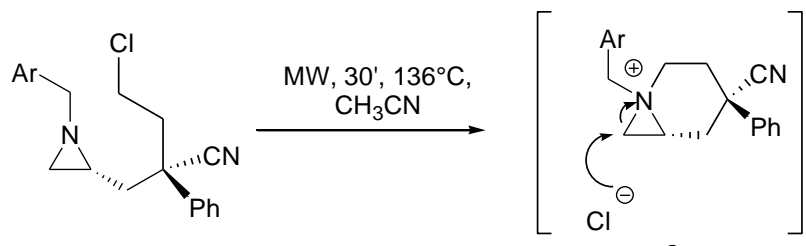

$8 \mathrm{a}-\mathrm{c}$

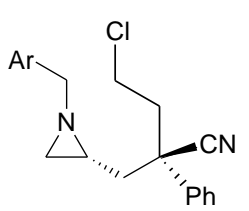

7a-c

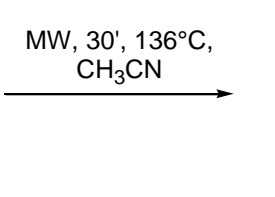

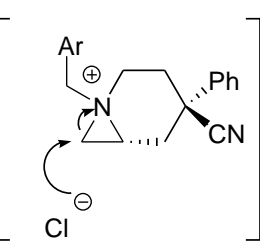

10a-c
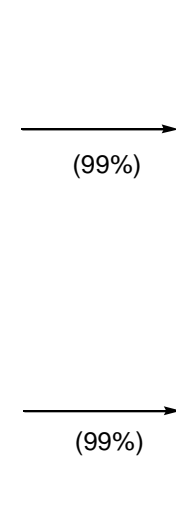

a: $\mathrm{Ar}=\mathrm{C}_{6} \mathrm{H}_{5}, \mathbf{b}: \mathrm{Ar}=4-\mathrm{MeC}_{6} \mathrm{H}_{4}, \mathrm{c}: \mathrm{Ar}=4-\mathrm{ClC}_{6} \mathrm{H}_{4}$

2-Chloromethyl-4-phenylpiperidine-4-carbonitriles 9 and $\mathbf{1 1}$ exhibit a number of interesting structural characteristics, making them suitable substrates for further elaboration. For example, the presence of a cyano substituent at the 4-position of the piperidine backbone provides an entry into conformationally restricted amino acid derivatives. Additionally, the 2-chloromethyl moiety is susceptible to nucleophilic substitution reactions, both intra- and intermolecularly.

$\beta$ - and $\gamma$-Amino acids are known to possess unique pharmacological properties, and their applications as building blocks for the corresponding $\beta$ - and $\gamma$-peptides make these compounds of high relevance in synthetic and medicinal chemistry. ${ }^{18}$ Besides their use in peptidomimetics, some $\beta$-amino acids exhibit strong antibacterial activity (e.g. cispentacin), ${ }^{18 b}$ while $\gamma$-amino acids are used for the treatment of epilepsy, Parkinson disease and schizophrenia (e.g. GABA-analogues). ${ }^{19}$ In continuation of our interest in $\beta$-amino acid chemistry, ${ }^{20}$ intensive efforts were devoted to the development of new entries toward different constrained amino acids bearing a piperidine moiety in their structure starting from the corresponding nitriles. Due to the synthetic utility of nitriles as precursors of 
carboxylic acids, esters and amides, the search for novel types of functionalized aminonitriles has become an important challenge in organic synthesis. ${ }^{21}$

In a first part of this work, cis-piperidine $9 \mathrm{c}$ was hydrolyzed utilizing a $\mathrm{HCl}(3 \mathrm{M}) / \mathrm{HOAc}(6 \mathrm{M})$ mixture in water under microwave irradiation for $1 \mathrm{~h}$ at $150^{\circ} \mathrm{C}$, resulting in the formation of an inseparable mixture of 2-(chloromethyl)- and 2-(hydroxymethyl)piperidines 12 and 13 (ratio 2/3). Subsequently, this mixture was treated with 2 equiv of $\mathrm{LiOH}$ in water for 30 minutes under reflux, followed by purification on Dowex $\left(\mathrm{H}^{+}, 50 \times 8-100\right)$, furnishing ammonium cis-1-(4-chlorobenzyl)-2-hydroxymethyl4-phenylpiperidine-4-carboxylate $\mathbf{1 4}$ as the sole reaction product in $80 \%$ yield (Scheme 3).

Furthermore, trans-piperidine 11c was subjected to similar reaction conditions as cis-isomer 9c, i.e. hydrolysis using a $\mathrm{HCl}(3 \mathrm{M}) / \mathrm{HOAc}(6 \mathrm{M})$ mixture in water under microwave irradiation for $1 \mathrm{~h} 40$ at $150^{\circ} \mathrm{C}$, furnishing trans-1-(4-chlorobenzyl)-2-chloromethyl-4-phenylpiperidine-4-carboxylic acid $\mathbf{1 5}$ in $85 \%$ yield. Remarkably, no formation of the corresponding 2-(hydroxymethyl)piperidine was observed in the latter case, pointing to a considerable steric hindrance with regard to attack of the chlorinated carbon atom in piperidine 11c and 15. Stereodefined 4-phenylpiperidine-4-carboxylic acids 14 and 15 represent a new class of constrained $\gamma$-amino acids with biological relevance. 

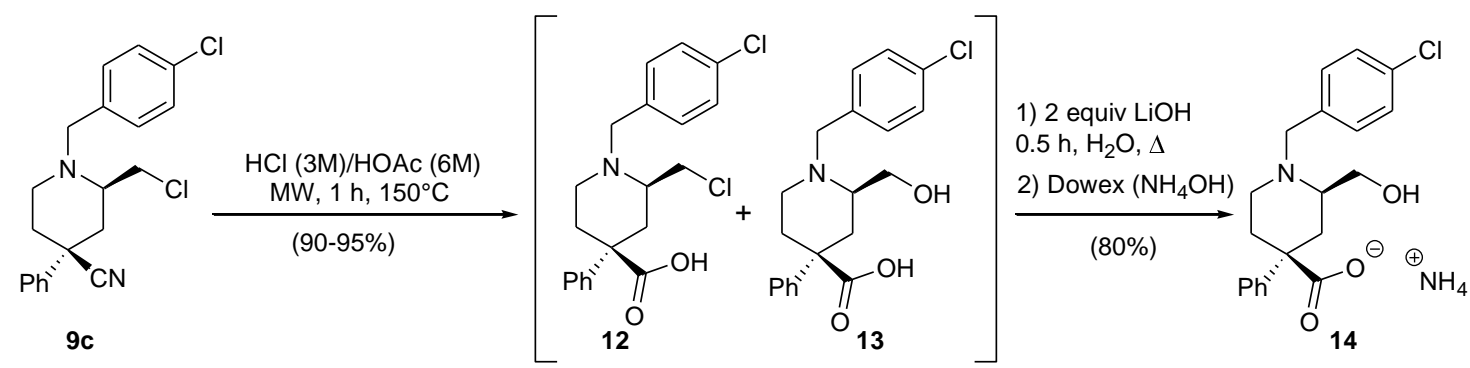

$(12 / 13,2 / 3)$

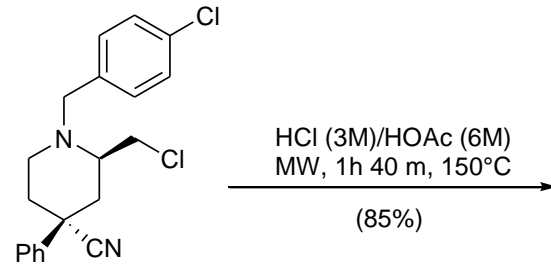

$11 \mathrm{c}$

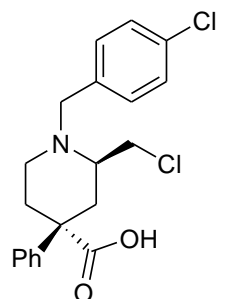

15

In light of the known biological importance of 3-aminoadipic acids, ${ }^{22}$ efforts were made for the preparation of novel conformational constrained analogues bearing a piperidine framework. Thus, cis-2-chloromethyl-4-phenylpiperidine-4-carbonitrile 9c was treated with 2 equiv of potassium cyanide in DMSO, furnishing the corresponding cis-2-cyanomethyl-4-phenylpiperidine-4-carbonitrile 16 after 1 hour at $120^{\circ} \mathrm{C}$ in $92 \%$ yield. From a mechanistic viewpoint, piperidine 9c probably undergoes an intramolecular substitution reaction toward bicyclic aziridinium intermediate $\mathbf{8 c}$, followed by regiospecific ring opening of this aziridinium salt by cyanide at the least hindered position, although direct $\mathrm{S}_{\mathrm{N}} 2$-substitution at the chlorinated atom cannot be excluded. Upon 3Danalysis of intermediate $8 \mathrm{c}$, the occurrence of a favorable $\pi$ - $\pi$-stacking ${ }^{23}$ between both aromatic rings can be observed, which results in steric hindrance at the substituted aziridinium carbon atom. This effect might (partially) explain the exclusive attack at the unhindered position occurred, resulting in the selective formation of piperidine $\mathbf{1 6}$. Next, both cyano groups in compound $\mathbf{1 6}$ were transformed to the corresponding carboxylic acids by acid hydrolysis. Thus, treatment of dicyanopiperidine 16 with a $\mathrm{HCl}(3 \mathrm{M}) / \mathrm{HOAc}(6 \mathrm{M})$ mixture in water gave rise to cis-2-carboxymethyl-1-(4-chlorobenzyl)-4- 
phenylpiperidine-4-carboxylic acid $\mathbf{1 7}$ in $\mathbf{9 5 \%}$ yield as a new constrained analogue of 3-aminoadipic acid after reflux for 3 days (Scheme 4).

Analogously, trans-1-(4-chlorobenzyl)-2-chloromethyl-4-phenylpiperidine-4-carbonitrile 11c was treated with 2 equiv of potassium cyanide in DMSO, resulting in a mixture of azepane-3,5dicarbonitrile 18 and 2-(cyanomethyl)piperidine-4-carbonitrile 19 (ratio 3/10) after 1 hour at $120{ }^{\circ} \mathrm{C}$. Probably, due to the absence of $\pi$ - $\pi$-stacking interaction, competition between attack at the unsubstituted and the substituted position in aziridinium intermediate $10 \mathrm{c}$ occurred, resulting in a mixture of azepane 18 and piperidine 19. Interestingly, azepane 18 could be easily transformed into the thermodynamically more stable piperidine 19 by heating the mixture of azepane 18 and piperidine 19 in DMSO at $120^{\circ} \mathrm{C}$ for 4 hours, affording 2-(cyanomethyl)piperidine 19 as the sole reaction product. Eventually, a nitrile to acid functional group transformation was performed in acidic medium $\left(\mathrm{HCl}(3 \mathrm{M}) / \mathrm{HOAc}(6 \mathrm{M})\right.$ in $\mathrm{H}_{2} \mathrm{O}$ under reflux for 6 days), furnishing trans-2carboxymethyl-1-(4-chlorobenzyl)-4-phenylpiperidine-4-carboxylic acid 20 in 95\% yield (Scheme 4). In summary, the above-described methodology allows the stereoselective preparation of both diastereomers of 2-carboxymethyl-4-phenylpiperidine-4-carboxylic acids $\mathbf{1 7}$ and $\mathbf{2 0}$ as biologically relevant targets, underlyning to the synthetic utility of this approach. 

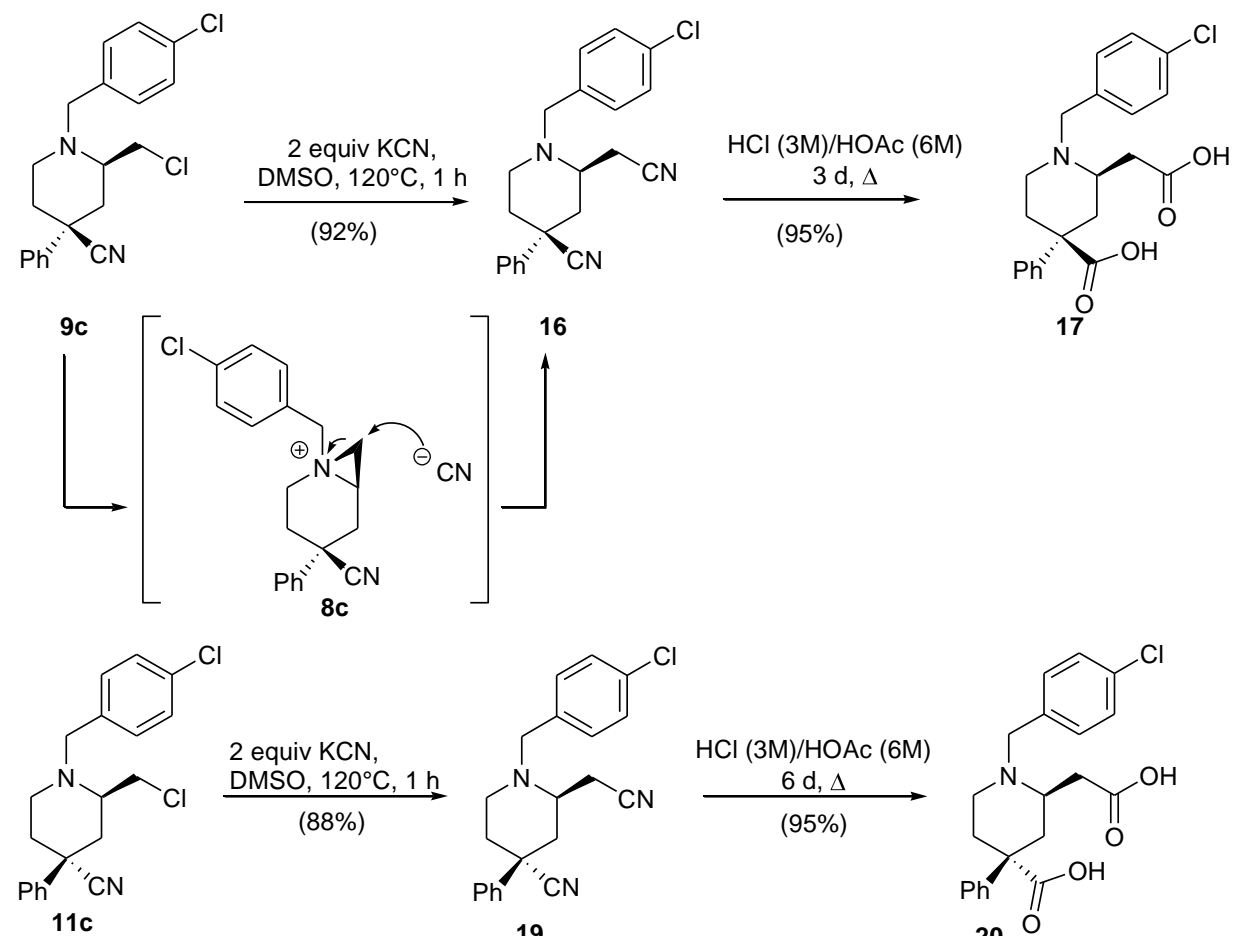

$\mathrm{HCl}(3 \mathrm{M}) / \mathrm{HOAC}(6 \mathrm{M})$
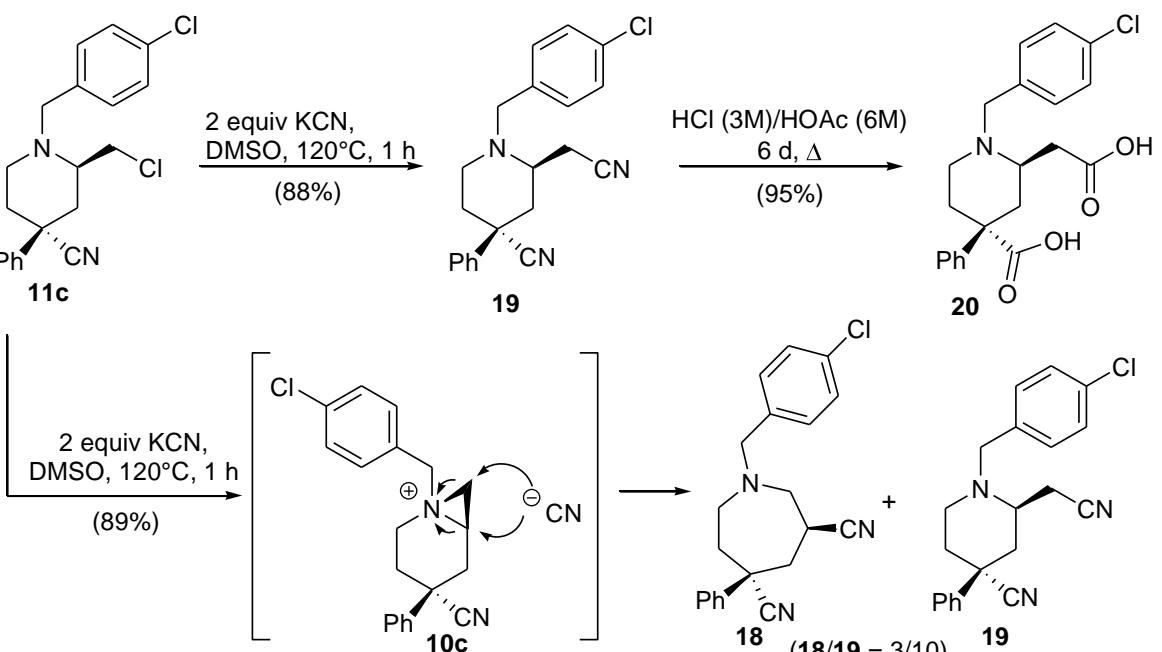

19

20

In addition to cyanide, acetate was used as an oxygen nucleophile for the synthesis of versatile $\beta$ amino alcohols using the same approach as described above. $\beta$-Amino alcohols comprise an important class of compounds, as this moiety is found in a wide variety of biologically active alkaloids and peptides. ${ }^{24}$ Furthermore, $\beta$-amino alcohols find applications as building blocks in the synthesis of various natural products and pharmaceuticals, ${ }^{25}$ and they are useful as chiral auxiliaries for asymmetric synthesis and catalysis. ${ }^{26}$

cis-2-Chloromethyl-4-phenylpiperidine-4-carbonitriles 9a,c were treated with 2 equiv of sodium acetate in ethanol, affording cis-6-acetoxy-4-phenylazepane-4-carbonitriles 21 and cis-2acetoxymethyl-4-phenylpiperidine-4-carbonitriles 22 in a ratio of $1 / 2$ after 2 hours under reflux (Scheme 5). Again, the reaction proceeded via intermediate bicyclic aziridinium salts $\mathbf{8 a , c}$, followed 
by preferential ring opening of the latter salts by acetate at the least hindered position. In this case, prolonged heating did not afford a single thermodynamic product, in contrast with the synthesis of aminonitriles 19 (Scheme 4). Furthermore, changing the solvent from ethanol to DMSO did not alter the isomeric ratio of the obtained products $\mathbf{2 1}$ and $\mathbf{2 2}$. Unfortunately, piperidines $\mathbf{2 2}$ and azepanes $\mathbf{2 1}$ appeared to be inseparable by column chromatography on silica gel.

Finally, acetates $\mathbf{2 1} \mathbf{b}$ and $\mathbf{2 2} \mathbf{b}$ were hydrolyzed using 2 equiv of lithium hydroxide in methanol under reflux for two hours, furnishing a mixture of cis-6-hydroxy-4-phenylazepane-4-carbonitrile $\mathbf{2 3}$ and cis2-hydroxymethyl-4-phenylpiperidine-4-carbonitrile 24 in $83 \%$ yield (Scheme 5). Piperidine 24 was separated through column chromatography on silica gel, providing a pure sample suitable for full spectroscopic characterization.

Analogously, trans-piperidine 11c was subjected to a nucleophilic substitution reaction using sodium acetate in ethanol. In this case, the reaction proceeded more sluggishly, and only after 13 hours of reflux the substrate was consumed completely, affording a mixture of trans-6-acetoxy-4phenylazepane-4-carbonitrile 25 and trans-2-acetoxymethyl-4-phenylpiperidine-4-carbonitrile 26 $(25 / 263 / 1)$. Due to the long reaction time, partial formation (26\%) of hydrolyzed products 27 and 28 was observed as well under the given reaction conditions, making a full characterization of acetates $\mathbf{2 5}$ and $\mathbf{2 6}$ impossible. In an attempt to shorten the reaction time, experiments were conducted using microwave irradiation, resulting in a reduction of the conversion time from 13 hours to 20 minutes at $110^{\circ} \mathrm{C}$ using 2 equiv of $\mathrm{NaOAc}$ in $\mathrm{EtOH}$ at 200 Watt. Also in this case, the reaction mixture contained a mixture of both the acetates $\mathbf{2 5}$ and $\mathbf{2 6}$ as major components (74\%) and alcohols $\mathbf{2 7}$ and $\mathbf{2 8}$ as minor impurities (26\%).

Again, functional group transformation of the acetate to corresponding alcohol was performed using 2 equiv of $\mathrm{LiOH}$ in $\mathrm{MeOH}$ for 1 hour at reflux temperature, furnishing trans-6-hydroxy-4phenylazepane-4-carbonitrile $\mathbf{2 7}$ and trans-2-hydroxymethyl-4-phenylpiperidine-4-carbonitrile $\mathbf{2 8}$ in $79 \%$ yield in a ratio of $3 / 1(\mathbf{2 7} / \mathbf{2 8})$. Carbonitrile 27 was separated via column chromatography on silica gel, affording a analytically pure sample. 
It should be remarked that, starting from cis-piperidines $9 a, c$, the preferential formation of piperidines $\mathbf{2 2}$ was observed, whereas azepane $\mathbf{2 5}$ was the major reaction product if trans-piperidine 11c was used as a substrate. This observation can partially be explained considering $\pi$ - $\pi$-stacking in intermediate $\mathbf{8 a , c}$, making an attack at the substituted aziridinium carbon atom more difficult due to steric hindrance. In addition, the polarizability of the nucleophiles might play an important role with regard to the regioselectivity, with cyanide being a strong and acetate a moderate nucleophile.

\section{SCHEME 5}<smiles>NC1(c2ccccc2)CCN(Cc2ccc(P)cc2)C(CCl)C1</smiles>

2 equiv $\mathrm{NaOAc}$, $\mathrm{EtOH}, \Delta, 2 \mathrm{~h}$ (96-97\%) $9 a, c$

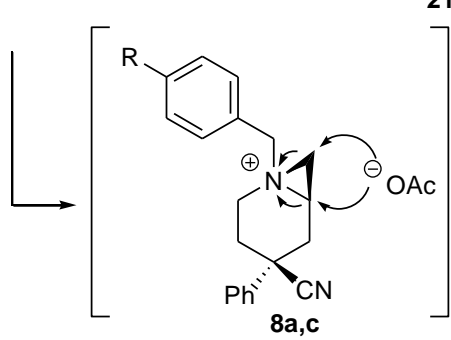<smiles>[R]OC1CC(C#N)(c2ccccc2)CCN1Cc1ccc(P)cc1</smiles>

21a $(\mathrm{R}=\mathrm{Me})$ $21 \mathrm{~b}(\mathrm{R}=\mathrm{Cl})$ $(21 / 22=1 / 2)$<smiles>N#CC1(c2ccccc2)CCN(Cc2ccc(P)cc2)C1COO</smiles>
22a $(R=M e)$ 22b $(\mathrm{R}=\mathrm{Cl})$<smiles>CN(c1ccccc1)C1C[C@H](O)C[C@](C#N)(c2ccccc2)CC1CO</smiles>

$(\mathbf{2 3} / \mathbf{2 4}=1 / 2)$ 
Finally, attempts were made to induce dehydrochlorination of 2-chloromethyl-4-phenylpiperidine-4carbonitriles 9 and 11, followed by migration of the double bound toward the thermodynamically more stable endocyclic position in order to form tetrahydropyridine-4-carbonitriles. Many bases ( $\mathrm{KOtBu}, \mathrm{NaH}, \mathrm{LDA}$ ) and solvents (THF, $t \mathrm{BuOH}, \mathrm{DMSO}$ ) were used, but complex reaction mixtures were obtained in all cases.

Next to intermolecular nucleophilic substitutions with cyanide and acetate, an intramolecular reaction of cis-2-(chloromethyl)piperidines 9 was examined, taking advantage of the presence of a nitrile group at the 4-position as a masked aminomethyl moiety. Gratifyingly, treatment of piperidines 9 with 2 equiv of $\mathrm{LiAlH}_{4}$ in THF afforded 5-phenyl-2,7-diazabicyclo[3.3.1]nonanes 29 as single reaction products (Scheme 6, yields after purification). This conversion proceeded via the formation of an aminomethyl substituent through cyanide reduction, which subsequently induced an intramolecular 6-exo-tet ring closure toward 5-phenyl-2,7-diazabicyclo[3.3.1]nonanes 29 by attack of the free amino moiety onto the chlorinated carbon atom. At first sight, it cannot be excluded that this ring closing reaction proceeds via an intermediate bicyclic aziridinium salt $\mathbf{8}$ as described above, which might give rise to 6-phenyl-3,8-diazabicyclo[4.2.1]nonanes upon ring opening as an alternative for 5-phenyl-2,7-diazabicyclo[3.3.1]nonanes 29. In order to confirm the presence of a bicyclo[3.3.1]nonane instead of a bicyclo[4.2.1]nonane skeleton in the obtained reaction products, the free amino group at the 7-position was protected with a tert-butoxycarbonyl group using 1.1 equiv of di-tert-butyl dicarbonate, 1.1 equiv of pyridine and DMAP (10 mol\%) as the catalyst in $\mathrm{CH}_{2} \mathrm{Cl}_{2}$ for 3 hours at room temperature (Scheme 6). This protection step resulted in substantial shifts of the signals of two $\mathrm{CH}_{2} \mathrm{~N}$ carbon atoms in the Boc-protected amine $30(46.39 \mathrm{ppm} \rightarrow 42.84 \mathrm{ppm}$ and $58.68 \mathrm{ppm} \rightarrow 53.19 \mathrm{ppm},{ }^{13} \mathrm{C}-\mathrm{NMR}, \mathrm{CDCl}_{3}$ ), whereas a less pronounced shift was observed for the CHN signal (52.09 ppm $\rightarrow 50.82 \mathrm{ppm}$ ). These observations point into the direction of a bicyclo[3.3.1]nonane backbone. In order to resolve all doubts, X-ray analysis of compound 29c unambiguously assigned the 5-phenyl-2,7-diazabicyclo[3.3.1]nonane system present in compounds 29 obtained through reduction of piperidines 9 by $\mathrm{LiAlH}_{4}$ (See supporting information). 
In this way, a convenient entry toward the 2,7-diazabicyclo[3.3.1]nonane ${ }^{28}$ skeleton is presented through a straightforward approach. These compounds $\mathbf{2 9}$ can be regarded as novel aza-analogues of 5-phenylmorphans 32, which act as opioid agonists or antagonists. ${ }^{29}$

In analogy, trans-piperidines $\mathbf{1 1 a , b}$ were treated with 2 equiv of $\mathrm{LiAlH}_{4}$ in THF under refux for two hours, resulting in the formation of trans-4-aminomethyl-2-methyl-4-phenylpiperidines 31 in 60-65\% yield (Scheme 6). The dechlorination of 2-(chloromethyl)piperidines 11 can take place via initial formation of an intermediate aziridinium salt $\mathbf{1 0}$ or via direct dechlorination, following either an ionic or a radical pathway. ${ }^{30}$ 4-(Aminomethyl)piperidines have been patented as potent tachykinin antagonists for the treatment of pain and inflammation, ${ }^{4}$ and can be used for the treatment of epilepsy, anxiety and inflammatory diseases. ${ }^{31}$

\section{SCHEME 6}<smiles>[R]c1ccc(CN2CC[C@](N)(c3ccccc3)C[C@H]2CCl)cc1</smiles>

$9 a(R=H)$
$9 b(R=M e)$

$9 c(\mathrm{R}=\mathrm{Cl})$<smiles>[R]c1ccc(CN2CC[C@](C#N)(c3ccccc3)C[C@H]2CCl)cc1</smiles>

11a $(\mathrm{R}=\mathrm{H})$ $11 b(R=M e)$
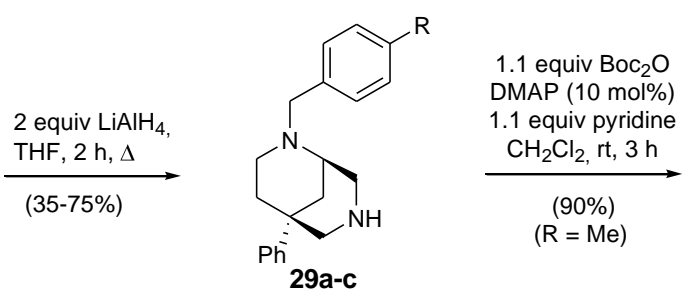

$(35-75 \%)$

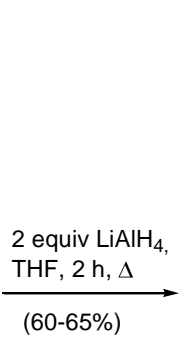

$(60-65 \%)$

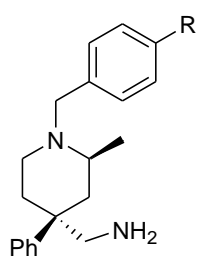

$31 a-b$
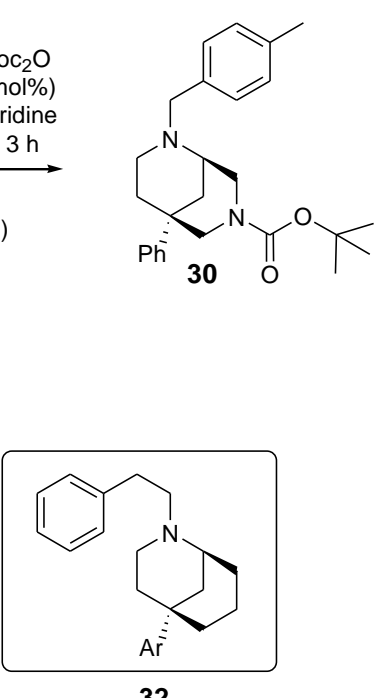

In conclusion, a short and convenient approach toward novel cis- and trans-2-chloromethyl-4phenylpiperidine-4-carbonitriles is reported starting from 2-(2-cyano-2-phenylethyl)aziridines. Furthermore, the high synthetic flexibility of these piperidine building blocks was demonstrated by the synthesis of a variaty of stereodefined conformationally constrained amino acids, a -amino alcohols and unprecedented 2,7-diazabicyclo[3.3.1]nonanes. 


\section{Experimental Part}

\section{General}

${ }^{1} \mathrm{H}$ NMR spectra were recorded at $300 \mathrm{MHz}$ (JEOL ECLIPSE+) with tetramethylsilane as internal standard. ${ }^{13} \mathrm{C}$ NMR spectra were recorded at $75 \mathrm{MHz}$ (JEOL ECLIPSE+). Mass spectra were recorded on an Agilent 1100 series mass spectrometer using either a direct inlet system (electron spray, 4000 V) or LC-MS coupling (UV detector). IR spectra were recorded on a Perkin-Elemer Spectrum BX FT-IR spectrometer. All compounds were analysed in neat form with an ATR (Attenuated Total Reflectance) accessory. Melting points were measured using a Büchi B-540 apparatus and are uncorrected. Dichloromethane was distilled over calcium hydride, while diethyl ether and THF were distilled from sodium and sodium benzophenone ketyl before use. Microwave reactions were performed in a CEM Discover Microwave Reactor $\left(200 \mathrm{~W}_{\max }\right)$ in a $80 \mathrm{ml}$ sealed vessel using a fiber-optic temperature sensor.

\section{Synthesis of 4-chloro-2-[1-(arylmethyl)aziridin-2-ylmethyl]-2-phenylbutyronitriles 6 and 7.}

As a representative example, the synthesis of 4-chloro-2-[1-benzylaziridin-2-ylmethyl]-5phenylbutyronitriles $\mathbf{6 a}$ and $\mathbf{7 a}$ is described here. To an ice-cooled solution of diisopropylamine (60 mmol, 1.2 equiv) in dry THF (75 ml) was added $n$-BuLi (1.2 equiv, $2.5 \mathrm{M})$ via a syringe under nitrogen atmosphere, and the resulting solution was stirred for 15 minutes at $0^{\circ} \mathrm{C}$. Subsequently, a solution of 1-benzyl-2-(2-cyano-2-phenylethyl)aziridine $5 \mathrm{a}(50 \mathrm{mmol})^{12 \mathrm{~b}}$ in THF $(20 \mathrm{ml})$ was added via a syringe at $0^{\circ} \mathrm{C}$, and the resulting solution was stirred for $1 \mathrm{~h}$ at $0^{\circ} \mathrm{C}$. Finally, 1-bromo-2-chloroethane $(55 \mathrm{mmol}$, 1.1 equiv) was added via a syringe at $0^{\circ} \mathrm{C}$, and the reaction mixture was stirred for $1 \mathrm{~h}$ at $0^{\circ} \mathrm{C}$ under nitrogen atmosphere. The reaction mixture was poured into a saturated $\mathrm{NH}_{4} \mathrm{Cl}$ solution $(75 \mathrm{ml})$ and was extracted with $\mathrm{Et}_{2} \mathrm{O}(3 \times 75 \mathrm{ml})$. Drying $\left(\mathrm{MgSO}_{4}\right)$, filtration of the drying agent and evaporation of the solvent in vacuo afforded 4-chloro-2-[1-benzylaziridine-2-ylmethyl]-2-phenylbutyronitriles 6a and $7 a$ as a mixture of isomers ). Isolation of the mixture of $\left(2 R, 2^{\prime} R\right)$ - and $\left(2 S, 2^{\prime} S\right)$-isomers 6a was realized by means of a selective crystallization from ethanol, whereas the $\left(2 R, 2^{\prime} S\right)$ - and $\left(2 S, 2^{\prime} R\right)$ - 
isomers 7 a were obtained by column chromatography on silica gel (hexane/EtOAc 3/1). (2R, $\left.\mathbf{2}^{\prime} \boldsymbol{R}\right)$ and (2S, 2'S)-2-[1-Benzylaziridin-2-ylmethyl]-4-chloro-2-phenylbutyronitrile 6a. (38\%) White Crystals. $\mathrm{Mp}=79.7^{\circ} \mathrm{C} . R_{\mathrm{f}}=0.21$ (hexane/EtOAc 3/1). ${ }^{1} \mathrm{H}$ NMR $\left(\mathrm{CDCl}_{3}\right): \delta 1.39-1.47(2 \mathrm{H}, \mathrm{m}) ; 1.75(1 \mathrm{H}, \mathrm{d}$, $J=2.8 \mathrm{~Hz}) ; 2.03$ and $2.26(2 \mathrm{H}, 2 \times \mathrm{dd}, J=14.0,5.8,5.2 \mathrm{~Hz}) ; 2.38(1 \mathrm{H}, \mathrm{ddd}, J=13.7,11.3,5.1 \mathrm{~Hz}) ; 2.52$ $(1 \mathrm{H}, \mathrm{ddd}, J=13.7,11.1,5.4 \mathrm{~Hz}) ; 2.92$ and $3.23(2 \mathrm{H}, 2 \times \mathrm{d}, J=12.9 \mathrm{~Hz}) ; 3.19(1 \mathrm{H}, \mathrm{ddd}, J=11.0,10.9,4.8$ $\mathrm{Hz}) ; 3.56(1 \mathrm{H}, \mathrm{ddd}, J=11.1,11.0,5.3 \mathrm{~Hz}) ; 7.13-7.52(10 \mathrm{H}, \mathrm{m}) .{ }^{13} \mathrm{CNMR}\left(\mathrm{CDCl}_{3}\right) ; \delta 33.8\left(\mathrm{CH}_{2}\right) ; 35.2$ (CH); $39.4\left(\mathrm{CH}_{2}\right) ; 43.2\left(\mathrm{CH}_{2}\right) ; 44.2\left(\mathrm{CH}_{2}\right) ; 46.1(\mathrm{C}) ; 64.3\left(\mathrm{CH}_{2}\right) ; 121.4(\mathrm{C}) ; 126.1(\mathrm{CH}) ; 127.3(\mathrm{CH}) ; 128.3$ (CH); $128.5(\mathrm{CH}) ; 128.6(\mathrm{CH}) ; 129.4(\mathrm{CH}) ; 136.4(\mathrm{C}) ; 138.7$ (C). IR $\left(\mathrm{cm}^{-1}\right): \mathrm{v}_{\mathrm{CN}}=2236 . \mathrm{MS}(70 \mathrm{eV}): \mathrm{m} / \mathrm{z}$ (\%): 325/7 ( $\left.\mathrm{M}^{+}+1,100\right)$. Anal. Calcd for $\mathrm{C}_{20} \mathrm{H}_{21} \mathrm{ClN}_{2}$ : C 73.95; H 6.52; N 8.62. Found: C 74.23; H 6.87; N 8.49. (2S, 2'R)- and (2R, 2'S)-2-[1-Benzylaziridin-2-ylmethyl]-4-chloro-2-phenylbutyronitrile 7a. (15\%) Yellow oil. $R_{\mathrm{f}}=0.13$ (hexane/EtOAc 3/1). ${ }^{1} \mathrm{H}$ NMR $\left(\mathrm{CDCl}_{3}\right): \delta 1.32(1 \mathrm{H}, \mathrm{d}, J=6.1 \mathrm{~Hz}) ; 1.40(1 \mathrm{H}, \mathrm{d}$, $J=3.9 \mathrm{~Hz}) ; 1.63-1.70(1 \mathrm{H}, \mathrm{m}) ; 2.02$ and $2.10(2 \mathrm{H}, 2 \times \mathrm{dd}, J=14.3,7.2,5.5 \mathrm{~Hz}) ; 2.34(1 \mathrm{H}, \mathrm{ddd}, J=13.8$, 11.3, $5.1 \mathrm{~Hz}) ; 2.48(1 \mathrm{H}, \mathrm{ddd}, J=13.8,11.0,5.5 \mathrm{~Hz}) ; 3.14(1 \mathrm{H}, \mathrm{ddd}, J=11.0,11.0,5.0 \mathrm{~Hz}) ; 3.46(1 \mathrm{H}$, $\mathrm{ddd}, J=11.0,11.0,5.6 \mathrm{~Hz}) ; 3.19$ and $3.64(2 \mathrm{H}, 2 \times \mathrm{d}, J=12.7 \mathrm{~Hz}) ; 7.23-7.47(1 \mathrm{H}, \mathrm{m}) .{ }^{13} \mathrm{C} \mathrm{NMR}\left(\mathrm{CDCl}_{3}\right) ; \delta$ $33.3\left(\mathrm{CH}_{2}\right) ; 35.4(\mathrm{CH}) ; 39.4\left(\mathrm{CH}_{2}\right) ; 42.4\left(\mathrm{CH}_{2}\right) ; 44.7\left(\mathrm{CH}_{2}\right) ; 46.1(\mathrm{C}) ; 64.6\left(\mathrm{CH}_{2}\right) ; 121.1(\mathrm{C}) ; 125.8(\mathrm{CH})$; $127.5(\mathrm{CH}) ; 128.5(\mathrm{CH}) ; 128.6(\mathrm{CH}) ; 128.6(\mathrm{CH}) ; 129.3(\mathrm{CH}) ; 137.1(\mathrm{C}) ; 138.5(\mathrm{C}) . \mathrm{IR}\left(\mathrm{cm}^{-1}\right): \mathrm{v}_{\mathrm{CN}}=2237$. MS (70 eV): $\mathrm{m} / \mathrm{z}(\%): 325 / 7\left(\mathrm{M}^{+}+1,100\right)$. Anal. Calcd for $\mathrm{C}_{20} \mathrm{H}_{21} \mathrm{CIN}_{2}$ : C 73.95; H 6.52; N 8.62. Found: $\mathrm{C}$ 74.20; H 6.72; N 8.51.

Synthesis of cis-1-arylmethyl-2-chloromethyl-4-phenylpiperidine-4-carbonitriles 9. As a representative example, the synthesis of cis-1-benzyl-2-chloromethyl-4-phenylpiperidine-4carbonitrile $9 a$ is described here. A solution of 2-[1-benzylaziridin-2-ylmethyl]-4-chloro-2phenylbutyronitrile $6 a(20 \mathrm{mmol})$ in acetonitrile $(20 \mathrm{ml})$ was placed in a $80 \mathrm{ml}$ sealed glass vessel, provided with an appropriate stirring bar and subjected to microwave conditions $\left(136^{\circ} \mathrm{C}, 30\right.$ minutes). Afterwards, evaporation of the solvent afforded cis-1-benzyl-2-chloromethyl-4phenylpiperidine-4-carbonitrile $\mathbf{9 a}$ in quantitative yield. cis-1-Benzyl-2-chloromethyl-4- 
phenylpiperidine-4-carbonitrile 9a. (99\%) Yellow oil. $R_{\mathrm{f}}=0.15$ (hexane/EtOAc 3/1). ${ }^{1} \mathrm{HNMR}\left(\mathrm{CDCl}_{3}\right): \delta$ 2.11-2.35 (3H, m); 2.56-2.66 (2H, m); $2.98(1 \mathrm{H}, \mathrm{ddd}, J=12.8,9.5,3.2 \mathrm{~Hz}) ; 3.16(1 \mathrm{H}, \mathrm{m}) ; 3.66$ and 3.87 $(2 \mathrm{H}, 2 \times \mathrm{d}, J=13.5 \mathrm{~Hz}) ; 3.87$ and $4.19(2 \mathrm{H}, 2 \times \mathrm{dd}, J=11.3,9.1,4.7 \mathrm{~Hz}) ; 7.23-7.52(10 \mathrm{H}, \mathrm{m}) .{ }^{13} \mathrm{C} \mathrm{NMR}$ $\left(\mathrm{CDCl}_{3}\right) ; \delta 35.0\left(\mathrm{CH}_{2}\right) ; 36.1\left(\mathrm{CH}_{2}\right) ; 38.5(\mathrm{C}) ; 42.3\left(\mathrm{CH}_{2}\right) ; 44.2\left(\mathrm{CH}_{2}\right) ; 58.4\left(\mathrm{CH}_{2}\right) ; 58.5(\mathrm{CH}) ; 124.0(\mathrm{C})$; $126.2(\mathrm{CH}) ; 127.5(\mathrm{CH}) ; 128.3(\mathrm{CH}) ; 128.6(\mathrm{CH}) ; 129.3(\mathrm{CH}) ; 138.6(\mathrm{C}) ; 139.4(\mathrm{C}) . \mathrm{IR}\left(\mathrm{cm}^{-1}\right): \mathrm{v}_{\mathrm{CN}}=2231$. MS (70 eV): $\mathrm{m} / \mathrm{z}(\%): 325 / 7\left(\mathrm{M}^{+}+1,100\right)$. Anal. Calcd for $\mathrm{C}_{20} \mathrm{H}_{21} \mathrm{ClN}_{2}$ : C 73.95; H 6.52; N 8.62. Found: C $74.31 ;$ H $6.74 ;$ N 8.49 .

Synthesis of trans-1-arylmethyl-2-chloromethyl-4-phenylpiperidine-4-carbonitriles 11 . As a representative example, the synthesis of trans-1-benzyl-2-chloromethyl-4-phenylpiperidine-4carbonitrile 11a is described here. A solution of 2-[1-benzylaziridin-2-ylmethyl]-4-chloro-2phenylbutyronitrile $7 \mathrm{a}(17.5 \mathrm{mmol})$ in acetonitrile $(20 \mathrm{ml})$ was placed in a $80 \mathrm{ml}$ sealed glass vessel, provided with an appropriate stirring bar and subjected to microwave conditions $\left(136^{\circ} \mathrm{C}, 30\right.$ minutes). Afterwards, evaporation of the solvent afforded trans-1-benzyl-2-chloromethyl-4phenylpiperidine-4-carbonitrile $\mathbf{1 1 a}$ in a quantitative yield. trans-1-Benzyl-2-chloromethyl-4phenylpiperidine-4-carbonitriles 11a. (99\%) White Crystals. $\mathrm{Mp}=115.1^{\circ} \mathrm{C} . R_{\mathrm{f}}=0.21$ (hexane/EtOAC 3/1). ${ }^{1} \mathrm{H}$ NMR $\left(\mathrm{CDCl}_{3}\right): \delta$ 1.98-2.02 $(2 \mathrm{H}, \mathrm{m}) ; 2.14-2.28(2 \mathrm{H}, \mathrm{m}) ; 2.57(1 \mathrm{H}, \mathrm{ddd}, J=12.5,8.4,6.2 \mathrm{~Hz})$; 2.95-3.05 (2H, m); $3.18(1 \mathrm{H}, \mathrm{d}, J=13.2 \mathrm{~Hz}) ; 3.63$ and $3.96(2 \mathrm{H}, 2 \times \mathrm{dd}, J=12.1,5.0,1.7 \mathrm{~Hz}) ; 4.21(1 \mathrm{H}, \mathrm{d}$, $J=13.2 \mathrm{~Hz}) ; 7.23-7.51(10 \mathrm{H}, \mathrm{m}) .{ }^{13} \mathrm{C} \mathrm{NMR}\left(\mathrm{CDCl}_{3}\right) ; \delta 35.9\left(\mathrm{CH}_{2}\right) ; 40.9\left(\mathrm{CH}_{2}\right) ; 43.3(\mathrm{C}) ; 46.6\left(\mathrm{CH}_{2}\right) ; 49.3$ $\left(\mathrm{CH}_{2}\right) ; 57.3\left(\mathrm{CH}_{2}\right) ; 59.1(\mathrm{CH}) ; 122.2(\mathrm{C}) ; 125.7(\mathrm{CH}) ; 127.4(\mathrm{CH}) ; 128.4(\mathrm{CH}) ; 128.6(\mathrm{CH}) ; 129.2(\mathrm{CH})$; 138.4 (C); 139.9 (C). IR $\left(\mathrm{cm}^{-1}\right): v_{C N}=2233 . M S(70 \mathrm{eV}): \mathrm{m} / \mathrm{z}(\%): 325 / 7\left(\mathrm{M}^{+}+1,100\right)$. Anal. Calcd for $\mathrm{C}_{20} \mathrm{H}_{21} \mathrm{ClN}_{2}$ : C 73.95; H 6.52; N 8.62. Found: C 74.11; H 6.68; N 8.66.

\section{Synthesis of ammonium cis-1-(4-chlorobenzyl)-2-hydroxymethyl-4-phenylpiperidine-4-carboxylate}

14. To a solution of cis-1-(4-chlorobenzyl)-2-chloromethyl-4-phenylpiperidine-4-carbonitrile (1.4 $\mathrm{mmol}) 9 \mathrm{c}$ in water $(5 \mathrm{ml})$ was added $3 \mathrm{M}$ hydrochloric acid $(1.62 \mathrm{ml})$ and $6 \mathrm{M}$ acetic acid $(3.42 \mathrm{ml})$. The 
mixture was placed in a $80 \mathrm{ml}$ sealed glass vessel, provided with an appropriate stirring bar and subjected to microwave conditions $\left(150^{\circ} \mathrm{C}, 1\right.$ hour). Afterwards, the solvent was evaporated under high vacuum, and the residue was redisolved in water $(10 \mathrm{ml})$. Subsequently, LiOH $(2.4 \mathrm{mmol}, 2$ equiv) was added to this solution, after which the resulting mixture was heated under reflux for 30 minutes. Isolation of ammonium cis-1-(4-chlorobenzyl)-2-hydroxymethyl-4-phenylpiperidine-4carboxylate 14 was realized by means of ion exchange chromatography on Dowex $\mathrm{H}^{+}$(50X8-100). Ammonium cis-1-(4-chlorobenzyl)-2-hydroxymethyl-4-phenylpiperidine-4-carboxylate 14. (80\%)White Crystals. $\mathrm{Mp}=228.3^{\circ} \mathrm{C} .{ }^{1} \mathrm{H}$ NMR $\left(\mathrm{CD}_{3} \mathrm{OD}\right): \delta 2.14(1 \mathrm{H}, \mathrm{ddd}, J=14.9,11.6,3.6 \mathrm{~Hz}) ; 2.26$ $(1 \mathrm{H}, \mathrm{dd}, J=14.9,11.0 \mathrm{~Hz}) ; 2.45(1 \mathrm{H}, \mathrm{dt}, J=12.2,2.4 \mathrm{~Hz}) ; 2.58(1 \mathrm{H}, \mathrm{d}($ broad $), J=14.9 \mathrm{~Hz}) ; 2.74(1 \mathrm{H}, \mathrm{d}$ (broad), $J=14.9 \mathrm{~Hz}) ; 2.83-2.86(1 \mathrm{H}, \mathrm{m}) ; 2.95(1 \mathrm{H}, \mathrm{dt}, J=12.2,3.6 \mathrm{~Hz}) ; 3.57(1 \mathrm{H}, \mathrm{d}, J=13.2 \mathrm{~Hz}) ; 3.78$ and $3.93(2 \mathrm{H}, 2 \times \mathrm{dd}, J=12.1,5.0,3.9 \mathrm{~Hz}) ; 4.36(1 \mathrm{H}, \mathrm{d}, J=13.2 \mathrm{~Hz}) ; 7.16-7.50(9 \mathrm{H}, \mathrm{m}) .{ }^{13} \mathrm{C} \mathrm{NMR}$ $\left(\mathrm{CD}_{3} \mathrm{OD}\right) ; \delta 30.6\left(\mathrm{CH}_{2}\right) ; 34.3\left(\mathrm{CH}_{2}\right) ; 41.1(\mathrm{C}) ; 48.5\left(\mathrm{CH}_{2}\right) ; 55.6\left(\mathrm{CH}_{2}\right) ; 60.8(\mathrm{CH}) ; 61.3\left(\mathrm{CH}_{2}\right) ; 126.0(\mathrm{CH})$; 127.0 (CH); 128.2 (CH); 128.4 (CH); $131.8(\mathrm{CH}) ; 126.8$ (C); 134.2 (C); $141.5(\mathrm{C}) ; 180.5$ (C). IR ( $\left.\mathrm{cm}^{-1}\right): \mathrm{V}_{\mathrm{OH}}$ $=3365, v_{C O}=1579 . M S(70 \mathrm{eV}): \mathrm{m} / \mathrm{z}(\%): 360 / 2\left(\mathrm{M}^{+}+1,100\right)$. Anal. Calcd for $\mathrm{C}_{20} \mathrm{H}_{25} \mathrm{ClN}_{2} \mathrm{O}_{3}: \mathrm{C} 63.74 ; \mathrm{H}$ 6.69; N 7.43. Found: C 63.86; H 6.81; N 7.23.

Synthesis of trans-1-(4-chlorobenzyl)-2-chloromethyl-4-phenylpiperidine-4-carboxylic acid 15 . To a solution of trans-1-(4-chlorobenzyl)-2-chloromethyl-4-phenylpiperidine-4-carbonitrile (1.4 mmol) 11c in water $(5 \mathrm{ml})$ was added $3 \mathrm{M}$ hydrochloric acid $(1.62 \mathrm{ml})$ and $6 \mathrm{M}$ acetic acid $(3.42 \mathrm{ml})$. The mixture was placed in a $80 \mathrm{ml}$ sealed glass vessel, provided with an appropriate stirring bar and subjected to microwave conditions $\left(150^{\circ} \mathrm{C}, 1 \mathrm{~h} 40\right.$ hour). Afterwards, the solvent was evaporated under high vacuum, affording trans-1-(4-chlorobenzyl)-2-chloromethyl-4-phenylpiperidine-4-carboxylic acid 15 in good yield and high purity (> 95\% based on NMR analysis). trans-1-(4-Chlorobenzyl)-2chloromethyl-4-phenylpiperidine-4-carboxylic acid 15. (85\%) White Crystals. $\mathrm{Mp}=216.6^{\circ} \mathrm{C} .{ }^{1} \mathrm{H}$ NMR ( $\left.\mathrm{CD}_{3} \mathrm{OD}\right): \delta$ 1.92-2.03 $(1 \mathrm{H}, \mathrm{m}) ; 2.20(1 \mathrm{H}, \mathrm{dd}, J=14.5,12.4 \mathrm{~Hz}) ; 2.73(1 \mathrm{H}, \mathrm{d}$ (broad), $J=14.3 \mathrm{~Hz}) ; 2.89$ $(1 \mathrm{H}, \mathrm{dd}, J=14.5,2.5 \mathrm{~Hz},) ; 3.10(1 \mathrm{H}, \mathrm{dt}, J=13.3,2.5 \mathrm{~Hz}) ; 3.34(1 \mathrm{H}, \mathrm{ddd}, J=13.3,4.0,2.6 \mathrm{~Hz}) ; 3.81-3.86$ 
$(1 \mathrm{H}, \mathrm{m}) ; 4.05(1 \mathrm{H}, \mathrm{dd}, J=13.4,2.5 \mathrm{~Hz}) ; 4.13(1 \mathrm{H}, \mathrm{d}, J=13.2 \mathrm{~Hz}) ; 4.38-4.42(1 \mathrm{H}, \mathrm{m}) ; 4.70(1 \mathrm{H}, \mathrm{d}, J=$ 13.2 Hz); 7.18-7.48 (9H, m). ${ }^{13} \mathrm{C}$ NMR $\left(\mathrm{CD}_{3} \mathrm{OD}\right) ; \delta 30.0\left(\mathrm{CH}_{2}\right) ; 35.2\left(\mathrm{CH}_{2}\right) ; 42.8\left(\mathrm{CH}_{2}\right) ; 48.2(\mathrm{C}) ; 49.8$ $\left(\mathrm{CH}_{2}\right) ; 55.2\left(\mathrm{CH}_{2}\right) ; 62.3(\mathrm{CH}) ; 125.1(\mathrm{CH}) ; 127.7(\mathrm{CH}) ; 128.7(\mathrm{CH}) ; 129.3(\mathrm{CH}) ; 133.2(\mathrm{CH}) ; 127.4(\mathrm{C})$; 136.3 (C); 141.0 (C); 174.4 (C). IR $\left(\mathrm{cm}^{-1}\right): \mathrm{v}_{\mathrm{OH}}=3362, \mathrm{v}_{\mathrm{CO}}=1715 . \mathrm{MS}(70 \mathrm{eV}): \mathrm{m} / \mathrm{z}(\%): 378 / 80 / 82$ $\left(\mathrm{M}^{+}+1,100\right)$. Anal. Calcd for $\mathrm{C}_{20} \mathrm{H}_{21} \mathrm{Cl}_{2} \mathrm{NO}_{2}$ : C 63.50; $\mathrm{H}$ 5.60; N 3.70. Found: $\mathrm{C} 63.77 ; \mathrm{H}$ 5.95; N 3.51.

Synthesis of cis-1-(4-chlorobenzyl)-2-cyanomethyl-4-phenylpiperidine-4-carbonitrile 16. To a solution of cis-1-(4-chlorobenzyl)-2-chloromethyl-4-phenylpiperidine-4-carbonitrile (1.0 mmol) 9c in DMSO (10 $\mathrm{ml})$ was added potassium cyanide ( $2 \mathrm{mmol}, 2$ equiv), and the resulting solution was heated for 1 hour at $120^{\circ} \mathrm{C}$. The reaction mixture was poured into water $(10 \mathrm{ml})$ and extracted with $\mathrm{Et}_{2} \mathrm{O}(3 \times$ $10 \mathrm{ml})$. Drying $\left(\mathrm{MgSO}_{4}\right)$, filtration of the drying agent, and evaporation of the solvent in vacuo afforded cis-1-(4-chlorobenzyl)-2-cyanomethyl-4-phenylpiperidine-4-carbonitrile 16 , which was isolated in pure form by means of column chromatography on silica gel (hexane/EtOAc 3/1). cis-1-(4Chlorobenzyl)-2-cyanomethyl-4-phenylpiperidine-4-carbonitrile 16. (92\%) White Crystals. $\mathrm{Mp}=$ $135.3^{\circ} \mathrm{C} . R_{\mathrm{f}}=0.16$ (hexane/EtOAc 3/1). ${ }^{1} \mathrm{H}$ NMR $\left(\mathrm{CDCl}_{3}\right): \delta 2.08-2.25(2 \mathrm{H}, \mathrm{m}) ; 2.35$ and $2.45(2 \mathrm{H}, 2 \times \mathrm{dd}$, $J=14.4,5.0,3.6 \mathrm{~Hz}) ; 2.55-2.62(1 \mathrm{H}, \mathrm{m}) ; 2.80(1 \mathrm{H}, \mathrm{dd}, J=17.1,5.5 \mathrm{~Hz}) ; 2.82-2.90(1 \mathrm{H}, \mathrm{m}) ; 3.09(1 \mathrm{H}, \mathrm{dd}$, $J=17.1,8.3 \mathrm{~Hz}) ; 3.29-3.37(1 \mathrm{H}, \mathrm{m}) ; 3.55$ and $3.72(2 \mathrm{H}, 2 \times \mathrm{d}, J=13.2 \mathrm{~Hz}) ; 7.22-7.48(9 \mathrm{H}, \mathrm{m}) .{ }^{13} \mathrm{C} \mathrm{NMR}$ $\left(\mathrm{CDCl}_{3}\right) ; \delta 16.9\left(\mathrm{CH}_{2}\right) ; 34.9\left(\mathrm{CH}_{2}\right) ; 38.2\left(\mathrm{CH}_{2}\right) ; 38.4(\mathrm{C}) ; 43.5\left(\mathrm{CH}_{2}\right) ; 54.1(\mathrm{CH}) ; 57.6\left(\mathrm{CH}_{2}\right) ; 118.6(\mathrm{C})$; 123.9 (C); 126.1 (CH); 128.6 (CH); $128.8(\mathrm{CH}) ; 129.4(\mathrm{CH}) ; 130.0(\mathrm{CH}) ; 132.2$ (C); $136.6(\mathrm{C}) ; 138.9$ (C). IR $\left(\mathrm{cm}^{-1}\right): v_{\mathrm{CN}}=2249$. MS $(70 \mathrm{eV}): \mathrm{m} / \mathrm{z}(\%): 350 / 2\left(\mathrm{M}^{+}+1,100\right)$. Anal. Calcd for $\mathrm{C}_{21} \mathrm{H}_{20} \mathrm{ClN}_{3}: \mathrm{C} 72.09 ; \mathrm{H}$ 5.76; N 12.01. Found: C 72.19; H 5.84; N 11.93.

Synthesis of cis-2-carboxymethyl-1-(4-chlorobenzyl)-4-phenylpiperidine-4-carboxylic acid 17 . To a solution of cis-1-(4-chlorobenzyl)-2-cyanomethyl-4-phenylpiperidine-4-carbonitrile 16 (0.43 mmol) in water $(5 \mathrm{ml})$ was added $3 \mathrm{M}$ hydrochloric acid $(1.62 \mathrm{ml})$ and $6 \mathrm{M}$ acetic acid $(3.42 \mathrm{ml})$ at room temperature, and the resulting solution was heated under reflux for 3 days. Isolation of cis-2- 
carboxymethyl-1-(4-chlorobenzyl)-4-phenylpiperidine-4-carboxylic acid $\mathbf{1 7}$ was performed by crystallization from the resulting solution upon standing at room temperature for 2 days. cis-2Carboxymethyl-1-(4-chlorobenzyl)-4-phenylpiperidine-4-carboxylic acid 17. (95\%) White Crystals. $\mathrm{Mp}=169.5^{\circ} \mathrm{C} .{ }^{1} \mathrm{H}$ NMR $\left(\mathrm{CD}_{3} \mathrm{OD}\right): \delta 2.26-2.37(1 \mathrm{H}, \mathrm{m}) ; 2.39(1 \mathrm{H}, \mathrm{dd}, J=15.4,11.6 \mathrm{~Hz}) ; 2.78-2.90(2 \mathrm{H}$, m); $3.04(1 \mathrm{H}, \mathrm{dd}, J=17.3,7.4 \mathrm{~Hz}) ; 3.14(1 \mathrm{H}, \mathrm{d}, J=15.4 \mathrm{~Hz}) ; 3.24-3.31(2 \mathrm{H}, \mathrm{m}) ; 3.56-3.63(1 \mathrm{H}, \mathrm{m}) ; 3.98$ and $4.72(2 \mathrm{H}, 2 \times \mathrm{d}, J=13.2 \mathrm{~Hz}) ; 7.32-7.58(9 \mathrm{H}, \mathrm{m}) .{ }^{13} \mathrm{C}$ NMR $\left(\mathrm{CD}_{3} \mathrm{OD}\right) ; \delta 29.1\left(\mathrm{CH}_{2}\right) ; 34.7\left(\mathrm{CH}_{2}\right) ; 35.0$ $\left(\mathrm{CH}_{2}\right) ; 46.8(\mathrm{C}) ; 48.4\left(\mathrm{CH}_{2}\right) ; 55.8\left(\mathrm{CH}_{2}\right) ; 58.0(\mathrm{CH}) ; 127.1(\mathrm{CH}) ; 127.7(\mathrm{CH}) ; 127.7(\mathrm{CH}) ; 129.1(\mathrm{CH}) ; 132.9$ (CH); 136.0 (C); 136.8 (C); 171.8 (C); 175.1 (C). IR ( $\left.\mathrm{cm}^{-1}\right): \mathrm{v}_{\mathrm{OH}}=3010 \mathrm{v}_{\mathrm{CO}}=1724 . \mathrm{MS}(70 \mathrm{eV}): \mathrm{m} / \mathrm{z}(\%):$ 388/90 (M+1, 100). Anal. Calcd for $\mathrm{C}_{21} \mathrm{H}_{22} \mathrm{ClNO}_{4}$ : C 65.03; H 5.72; N 3.61. Found: C 65.46; H 5.92; N 3.48 .

Synthesis of trans-1-(4-chlorobenzyl)-5-phenylazepane-3,5-dicarbonitrile 18. To a solution of trans1-(4-chlorobenzyl)-2-chloromethyl-4-phenylpiperidine-4-carbonitrile $11 \mathrm{c}(0.5 \mathrm{mmol})$ in DMSO (10 ml) was added potassium cyanide $\left(1 \mathrm{mmol}, 2\right.$ equiv), and the resulting solution was heated at $120^{\circ} \mathrm{C}$ for 1 hour. The reaction mixture was poured into water $(10 \mathrm{ml})$ and extracted with $\mathrm{Et}_{2} \mathrm{O}(3 \times 10 \mathrm{ml})$. Drying $\left(\mathrm{MgSO}_{4}\right)$, filtration of the drying agent, and evaporation of the solvent in vacuo afforded a mixture of trans-1-(4-chlorobenzyl)-5-phenylazepane-3,5-dicarbonitrile 18 and trans-1-(4-chlorobenzyl)-2cyanomethyl-4-phenylpiperidine-4-carbonitrile 19 in a 3/10 ratio (18/19). trans-1-(4-Chlorobenzyl)5-phenylazepane-3,5-dicarbonitrile $\mathbf{1 8}$ was isolated in pure form by means of column chromatography on silica gel (hexane/EtOAc 3/1). trans-1-(4-Chlorobenzyl)-5-phenylazepane-3,5dicarbonitrile 18. (21\%) Yellow oil. $R_{\mathrm{f}}=0.22$ (hexane/EtOAc 3/1). ${ }^{1} \mathrm{H}$ NMR $\left(\mathrm{CDCl}_{3}\right): \delta 2.18-2.25(2 \mathrm{H}$, $\mathrm{m}) ; 2.45-2.51(2 \mathrm{H}, \mathrm{m}) ; 2.87-3.01(2 \mathrm{H}, \mathrm{m}) ; 3.03-3.24(3 \mathrm{H}, \mathrm{m}) ; 3.71$ and $3.81(2 \mathrm{H}, 2 \times \mathrm{d}, J=13.2 \mathrm{~Hz}) ; 7.26-$ $7.50(9 \mathrm{H}, \mathrm{m}) .{ }^{13} \mathrm{C} \mathrm{NMR}\left(\mathrm{CDCl}_{3}\right) ; \delta 29.9(\mathrm{CH}) ; 40.7\left(\mathrm{CH}_{2}\right) ; 42.2\left(\mathrm{CH}_{2}\right) ; 44.9(\mathrm{C}) ; 51.8\left(\mathrm{CH}_{2}\right) ; 55.0\left(\mathrm{CH}_{2}\right) ; 62.0$ $\left(\mathrm{CH}_{2}\right) ; 120.5(\mathrm{C}) ; 121.0(\mathrm{C}) ; 125.1(\mathrm{CH}) ; 128.5(\mathrm{CH}) ; 128.9(\mathrm{CH}) ; 129.4(\mathrm{CH}) ; 130.2(\mathrm{CH}) ; 133.4(\mathrm{C}) ; 136.8$ (C); $141.2(C)$. IR $\left(\mathrm{cm}^{-1}\right): \mathrm{v}_{\mathrm{CN}}=2238 . \mathrm{MS}(70 \mathrm{eV}): \mathrm{m} / \mathrm{z}(\%): 350 / 2\left(\mathrm{M}^{+}+1,100\right)$. Anal. Calcd for $\mathrm{C}_{21} \mathrm{H}_{20} \mathrm{ClN}_{3}$ : C 72.09; H 5.76; N 12.01. Found: C 71.90; H 5.86; N 12.17. 
Synthesis of trans-1-(4-chlorobenzyl)-2-cyanomethyl-4-phenylpiperidine-4-carbonitrile 19. To a solution of trans-1-(4-chlorobenzyl)-2-chloromethyl-4-phenylpiperidine-4-carbonitrile (1.0 mmol) 11c in DMSO (10 $\mathrm{ml})$ was added potassium cyanide $(2 \mathrm{mmol}, 2$ equiv), and the resulting solution was heated for 5 hours at $120^{\circ} \mathrm{C}$. The reaction mixture was poured into water $(10 \mathrm{ml})$ and extracted with $\mathrm{Et}_{2} \mathrm{O}(3 \times 10 \mathrm{ml})$. Drying $\left(\mathrm{MgSO}_{4}\right)$, filtration of the drying agent, and evaporation of the solvent in vacuo afforded trans-1-(4-chlorobenzyl)-2-cyanomethyl-4-phenylpiperidine-4-carbonitrile 19, which was isolated in pure form by means of column chromatography on silica gel (hexane/EtOAc 3/1). trans-1-(4-Chlorobenzyl)-2-cyanomethyl-4-phenylpiperidine-4-carbonitrile 19. (88\%) White Crystals. $\mathrm{Mp}=129.9^{\circ} \mathrm{C} . R_{\mathrm{f}}=0.16$ (hexane/EtOAc 3/1). ${ }^{1} \mathrm{H}$ NMR $\left(\mathrm{CDCl}_{3}\right): \delta 2.03-2.08(2 \mathrm{H}, \mathrm{m}) ; 2.11-2.25(2 \mathrm{H}, \mathrm{m})$; 2.50-2.59 $(2 \mathrm{H}, \mathrm{m}) ; 2.94-3.08(3 \mathrm{H}, \mathrm{m}) ; 3.18$ and $4.12(2 \mathrm{H}, 2 \times \mathrm{d}, J=12.9 \mathrm{~Hz}) ; 7.26-7.52(9 \mathrm{H}, \mathrm{m}) .{ }^{13} \mathrm{C} \mathrm{NMR}$ $\left(\mathrm{CDCl}_{3}\right) ; \delta 23.3\left(\mathrm{CH}_{2}\right) ; 35.6\left(\mathrm{CH}_{2}\right) ; 42.7\left(\mathrm{CH}_{2}\right) ; 43.2(\mathrm{C}) ; 49.3\left(\mathrm{CH}_{2}\right) ; 55.0(\mathrm{CH}) ; 57.1\left(\mathrm{CH}_{2}\right) ; 116.7(\mathrm{C})$; 121.7 (C); $125.6(\mathrm{CH}) ; 128.6(\mathrm{CH}) ; 128.8(\mathrm{CH}) ; 129.3(\mathrm{CH}) ; 130.3(\mathrm{CH}) ; 133.4(\mathrm{C}) ; 136.4(\mathrm{C}) ; 139.1(\mathrm{C}) . \mathrm{IR}$ $\left(\mathrm{cm}^{-1}\right): v_{\mathrm{CN}}=2248 . \mathrm{MS}(70 \mathrm{eV}): \mathrm{m} / \mathrm{z}(\%): 350 / 2\left(\mathrm{M}^{+}+1,100\right)$. Anal. Calcd for $\mathrm{C}_{21} \mathrm{H}_{20} \mathrm{ClN}_{3}: \mathrm{C} 72.09 ; \mathrm{H}$ 5.76; N 12.01. Found: C 72.21; H 5.93; N 11.92.

Synthesis of trans-2-carboxymethyl-1-(4-chlorobenzyl)-4-phenylpiperidine-4-carboxylic acid 20. To a solution of trans-1-(4-chlorobenzyl)-2-cyanomethyl-4-phenylpiperidine-4-carbonitrile 19 (0,65 $\mathrm{mmol})$ in water $(5 \mathrm{ml})$ was added $3 \mathrm{M}$ hydrochloric acid $(1.62 \mathrm{ml})$ and $6 \mathrm{M}$ acetic acid $(3.42 \mathrm{ml})$ at room temperature, and the resulting solution was heated under reflux for 6 days. Isolation of trans-2carboxymethyl-1-(4-chlorobenzyl)-4-phenylpiperidine-4-carboxylic acid $\mathbf{2 0}$ was performed by crystallization from the resulting solution upon standing at room temperature for 2 days. trans-2Carboxymethyl-1-(4-chlorobenzyl)-4-phenylpiperidine-4-carboxylic acid 20. (95\%) White Crystals. $\mathrm{Mp}=243.3^{\circ} \mathrm{C} .{ }^{1} \mathrm{H}$ NMR $\left(\left(\mathrm{CD}_{3}\right)_{2} \mathrm{SO}\right): \delta$ 1.88-2.02 $(2 \mathrm{H}, \mathrm{m}) ; 2.57(1 \mathrm{H}, \mathrm{d}, J=13.0 \mathrm{~Hz}) ; 2.74-2.82(2 \mathrm{H}, \mathrm{m}) ;$ $2.92(1 \mathrm{H}, \mathrm{t}, J=13.0 \mathrm{~Hz}) ; 3.12-3.25(2 \mathrm{H}, \mathrm{m}) ; 3.56-3.64(1 \mathrm{H}, \mathrm{m}) ; 4.11$ and $4.53(2 \mathrm{H}, 2 \times \mathrm{d}, J=13.0 \mathrm{~Hz})$; 7.24-7.53 (9H, m). ${ }^{13} \mathrm{C} \mathrm{NMR}\left(\left(\mathrm{CD}_{3}\right)_{2} \mathrm{SO}\right) ; \delta 30.0\left(\mathrm{CH}_{2} \mathrm{~N}\right) ; 36.9\left(\mathrm{CH}_{2}\right) ; 37.3\left(\mathrm{CH}_{2}\right) ; 48.3(\mathrm{C}) ; 49.3\left(\mathrm{CH}_{2}\right) ; 54.4$ 
$\left(\mathrm{CH}_{2}\right) ; 58.8(\mathrm{CH}) ; 125.7(\mathrm{CH}) ; 128.2(\mathrm{CH}) ; 129.4(\mathrm{CH}) ; 129.5(\mathrm{CH}) ; 133.7(\mathrm{CH}) ; 135.0(\mathrm{C}) ; 141.9(\mathrm{C}) ; 171.8$

(C); 174.6 (C). IR $\left(\mathrm{cm}^{-1}\right): \mathrm{v}_{\mathrm{OH}}=3240, \mathrm{v}_{\mathrm{CO}}=1742,1692 . \mathrm{MS}(70 \mathrm{eV}): \mathrm{m} / \mathrm{z}(\%): 388 / 90\left(\mathrm{M}^{+}+1,100\right)$. Anal. Calcd for $\mathrm{C}_{21} \mathrm{H}_{22} \mathrm{ClNO}_{4}$ : C 65.03; H 5.72; N 3.61. Found: C 65.41; H 5.94; N 3.39.

Synthesis of cis-6-acetoxy-1-arylmethyl-4-phenylazepane-4-carbonitriles 21 and cis-2acetoxymethyl-1-arylmethyl-4-phenylpiperidine-4-carbonitriles 22. As a representative example, the synthesis of cis-6-acetoxy-1-(4-chlorobenzyl)-4-phenylazepane-4-carbonitrile $\mathbf{2 1 b}$ and cis-2acetoxymethyl-1-(4-chlorobenzyl)-4-phenylpiperidine-4-carbonitrile $\mathbf{2 2 b}$ is presented here. To a solution of cis-1-(4-chlorobenzyl)-2-chloromethyl-4-phenylpiperidine-4-carbonitrile $9 \mathrm{c}(0.95 \mathrm{mmol})$ in ethanol ( $10 \mathrm{ml})$ was added sodium acetate $(1.9 \mathrm{mmol}, 2$ equiv), and the resulting solution was heated under reflux for 2 hours. The reaction mixture was poured into water $(10 \mathrm{ml})$ and extracted with $\mathrm{Et}_{2} \mathrm{O}$ $(3 \times 10 \mathrm{ml})$. Drying $\left(\mathrm{MgSO}_{4}\right)$, filtration of the drying agent, and evaporation of the solvent in vacuo afforded cis-6-acetoxy-1-(4-chlorobenzyl)-4-phenylazepane-4-carbonitrile $\quad \mathbf{2 1 b}$ and cis-2acetoxymethyl-1-(4-chlorobenzyl)-4-phenylpiperidine-4-carbonitrile $\mathbf{2 2} \mathbf{b}$. Isolation of pure samples of azepane $\mathbf{2 1} \mathbf{b}$ and piperidine $\mathbf{2 2} \mathbf{b}$ from the mixture by means of column chromatography on silica gel (hexane/EtOAc 9/1) was not possible, and spectral data were derived from the mixture of $\mathbf{2 1 b}$ and 22b.

cis-6-Acetoxy-1-(4-chlorobenzyl)-4-phenylazepane-4-carbonitrile 21b. Spectral data derived from a mixture of diastereomers. Yellow oil. $R_{\mathrm{f}}=0.16$ (hexane/EtOAc 9/1). ${ }^{1} \mathrm{H} \mathrm{NMR}\left(\mathrm{CDCl}_{3}\right): \delta 2.03(3 \mathrm{H}, \mathrm{s})$; 2.17-2.28 $(2 \mathrm{H}, \mathrm{m}) ; 2.49-2.56(2 \mathrm{H}, \mathrm{m}) ; 2.81-3.14(4 \mathrm{H}, \mathrm{m}) ; 3.62$ and $3.70(2 \mathrm{H}, 2 \times \mathrm{d}, J=13.8 \mathrm{~Hz}) ; 5.13-$ $5.22(1 \mathrm{H}, \mathrm{m}) ; 7.21-7.54(9 \mathrm{H}, \mathrm{m}) .{ }^{13} \mathrm{C}$ NMR $\left(\mathrm{CDCl}_{3}\right) ; \delta 21.3\left(\mathrm{CH}_{3}\right) ; 40.6\left(\mathrm{CH}_{2}\right) ; 42.3(\mathrm{C}) ; 43.4\left(\mathrm{CH}_{2}\right) ; 53.1$ $\left(\mathrm{CH}_{2}\right) ; 57.5\left(\mathrm{CH}_{2}\right) ; 62.3\left(\mathrm{CH}_{2}\right) ; 70.4(\mathrm{CH}) ; 122.9(\mathrm{C}) ; 125.4(\mathrm{CH}) ; 128.0(\mathrm{CH}) ; 128.3(\mathrm{CH}) ; 130.3(\mathrm{CH})$; 132.9 (C); 137.6 (C); 141.9 (C); 170.5 (C). IR ( $\left.\mathrm{cm}^{-1}\right): \mathrm{v}_{\mathrm{CO}}=1736 \mathrm{v}_{\mathrm{CN}}=2232 . \mathrm{MS}(70 \mathrm{eV}): \mathrm{m} / \mathrm{z}(\%): 383 / 5$ $\left(\mathrm{M}^{+}+1,100\right)$

cis-2-Acetoxymethyl-1-(4-chlorobenzyl)-4-phenylpiperidine-4-carbonitrile 22b. Spectral data derived from a mixture of diastereomers. Yellow oil. $R_{\mathrm{f}}=0.16$ (hexane/EtOAc 9/1). ${ }^{1} \mathrm{HNMR}\left(\mathrm{CDCl}_{3}\right): \delta$ 
$2.06(3 \mathrm{H}, \mathrm{s}) ; 2.08-2.28(2 \mathrm{H}, \mathrm{m}) ; 2.36(2 \mathrm{H}, \mathrm{d}, J=5.0 \mathrm{~Hz}) ; 2.49-2.56(1 \mathrm{H}, \mathrm{m}) ; 2.81-3.04(1 \mathrm{H}, \mathrm{m}) ; 3.07-3.14$ $(1 \mathrm{H}, \mathrm{m}) ; 3.59$ and $3.82(2 \mathrm{H}, 2 \times \mathrm{d}, J=13.8 \mathrm{~Hz}) ; 4.50$ and $4.57(2 \mathrm{H}, 2 \times \mathrm{dd}, J=11.9,6.1,5.8 \mathrm{~Hz}) ; 7.21-7.54$ (9H, m). ${ }^{13} \mathrm{C} \mathrm{NMR}\left(\mathrm{CDCl}_{3}\right) ; \delta 21.5\left(\mathrm{CH}_{3}\right) ; 35.0\left(\mathrm{CH}_{2}\right) ; 37.0\left(\mathrm{CH}_{2}\right) ; 38.6(\mathrm{C}) ; 44.6\left(\mathrm{CH}_{2} \mathrm{~N}\right) ; 56.0(\mathrm{CH}) ; 57.7$ $\left(\mathrm{CH}_{2}\right) ; 62.6\left(\mathrm{CH}_{2}\right) ; 123.9(\mathrm{C}) ; 126.2(\mathrm{CH}) ; 128.6(\mathrm{CH}) ; 129.2(\mathrm{CH}) ; 129.8(\mathrm{CH}) ; 130.0(\mathrm{CH}) ; 132.8(\mathrm{C})$; 137.6 (C); 139.3 (C); 170.8 (C). IR $\left(\mathrm{cm}^{-1}\right): v_{\mathrm{CO}}=1736 \mathrm{v}_{\mathrm{CN}}=2232 . \mathrm{MS}(70 \mathrm{eV}): \mathrm{m} / \mathrm{z}(\%): 383 / 5\left(\mathrm{M}^{+}+1,100\right)$.

Synthesis of cis-1-(4-chlorobenzyl)-2-hydroxymethyl-4-phenylpiperidine-4-carbonitrile 24. To a solution of cis-2-acetoxymethyl-1-(4-chlorobenzyl)-4-phenylpiperidine-4-carbonitrile $\mathbf{2 2 b}$ and cis-6acetoxy-1-(4-chlorobenzyl)-4-phenylazepane-4-carbonitriles $21 \mathbf{b}(0.6 \mathrm{mmol})$ in methanol $(10 \mathrm{ml})$ was added lithium hydroxide ( $1.3 \mathrm{mmol}, 2$ equiv), and the resulting solution was heated under reflux for 2 hours. The reaction mixture was poured into water $(10 \mathrm{ml})$ and extracted with $\mathrm{Et}_{2} \mathrm{O}(3 \times 10 \mathrm{ml})$. Drying $\left(\mathrm{MgSO}_{4}\right)$, filtration of the drying agent, and evaporation of the solvent in vacuo afforded a mixture of cis-1-(4-chlorobenzyl)-6-hydroxy-4-phenylazepane-4-carbonitrile 23 and cis-1-(4chlorobenzyl)-2-hydroxymethyl-4-phenylpiperidin-4-carbonitrile 24 in a ratio of 33-36/64-67 (23/24). The major isomer cis-1-(4-chlorobenzyl)-2-hydroxymethyl-4-phenylpiperidin-4-carbonitrile 24 was isolated and purified by means of column chromatography on silica gel (hexane/EtOAc 1/1). cis-1-(4Chlorobenzyl)-2-hydroxymethyl-4-phenylpiperidine-4-carbonitrile 24. $(55 \%)$ Yellow oil. $R_{\mathrm{f}}=0.34$ (hexane/EtOAc 1/1). ${ }^{1} \mathrm{H}$ NMR $\left(\mathrm{CDCl}_{3}\right): \delta 2.10(1 \mathrm{H}, \mathrm{ddd}, J=13.8,7.2,2.8 \mathrm{~Hz}) ; 2.29-2.40(3 \mathrm{H}, \mathrm{m}) ; 2.50$ $(1 \mathrm{H}, \mathrm{ddd}, J=13.4,7.2,3.2 \mathrm{~Hz}) ; 2.91(1 \mathrm{H}$, pent., $J=5.6 \mathrm{~Hz}) ; 3.03(1 \mathrm{H}, \mathrm{ddd}, J=13.4,8.7,2.8 \mathrm{~Hz}) ; 3.51$ and $3.89(2 \mathrm{H}, 2 \times d, J=13.5 \mathrm{~Hz}) ; 3.88$ and $4.00(2 \mathrm{H}, 2 \times \mathrm{dd}, J=11.6,6.1,5.5 \mathrm{~Hz}) ; 7.22-7.50(9 \mathrm{H}, \mathrm{m}) .{ }^{13} \mathrm{C}$ $\operatorname{NMR}\left(\mathrm{CDCl}_{3}\right) ; \delta 33.0\left(\mathrm{CH}_{2}\right) ; 35.1\left(\mathrm{CH}_{2}\right) ; 38.4(\mathrm{C}) ; 44.4\left(\mathrm{CH}_{2}\right) ; 57.4(\mathrm{CH}) ; 58.1\left(\mathrm{CH}_{2}\right) ; 60.9\left(\mathrm{CH}_{2}\right) ; 124.3(\mathrm{C}) ;$ $126.4(\mathrm{CH}) ; 128.4(\mathrm{CH}) ; 128.8(\mathrm{CH}) ; 129.3(\mathrm{CH}) ; 130.0(\mathrm{CH}) ; 133.2(\mathrm{C}) ; 137.2(\mathrm{C}) ; 138.9(\mathrm{C}) . \mathrm{IR}\left(\mathrm{cm}^{-1}\right)$ : $\mathrm{v}_{\mathrm{OH}}=3435 \mathrm{v}_{\mathrm{CN}}=2232 . \mathrm{MS}(70 \mathrm{eV}): \mathrm{m} / \mathrm{z}(\%): 341 / 3\left(\mathrm{M}^{+}+1,100\right)$. Anal. Calcd for $\mathrm{C}_{20} \mathrm{H}_{21} \mathrm{ClN}_{2} \mathrm{O}: \mathrm{C} 70.48 ; \mathrm{H}$ 6.21; N 8.22. Found: C 70.69; H 6.44; N 8.05 . 
Synthesis of trans-1-(4-chlorobenzyl)-6-hydroxy-4-phenylazepane-4-carbonitrile 27. To a solution of trans-1-(4-chlorobenzyl)-2-chloromethyl-4-phenylpiperidine-4-carbonitrile $11 \mathrm{c}(0.95 \mathrm{mmol})$ in ethanol (10 $\mathrm{ml})$ was added sodium acetate $(1.9 \mathrm{mmol}, 2$ equiv), and the resulting solution was heated under reflux for 13 hours. The reaction mixture was poured into water $(10 \mathrm{ml})$ and extracted with $\mathrm{Et}_{2} \mathrm{O}(3 \times 10 \mathrm{ml})$. Drying $\left(\mathrm{MgSO}_{4}\right)$, filtration of the drying agent and evaporation of the solvent afforded trans-6-acetoxy-1-(4-chlorobenzyl)-4-phenylazepane-4-carbonitrile 25 and trans-2acetoxymethyl-1-(4-chlorobenzyl)-4-phenylpiperidin-4-carbonitrile 26 in a ratio of 71-79/21-29 (25/26). Subsequently, acetates $\mathbf{2 5}$ and $\mathbf{2 6}$ were redissolved in $\mathrm{MeOH}$, after which lithium hydroxide (1.3 mmol, 2 equiv) was added and the resulting solution was heated under reflux for 1 hour. Afterwards, the reaction mixture was poured into water $(10 \mathrm{ml})$ and extracted with $\mathrm{Et}_{2} \mathrm{O}(3 \times 10 \mathrm{ml})$. Drying $\left(\mathrm{MgSO}_{4}\right)$, filtration of the drying agent and evaporation of the solvent in vacuo afforded a mixture of trans-1-(4-chlorobenzyl)-6-hydroxy-4-phenylazepane-4-carbonitrile 27 and trans-1-(4chlorobenzyl)-2-hydroxymethyl-4-phenylpiperidin-4-carbonitrile 28 in a 71-79/21-29 (27/28) ratio. The major constituent, trans-1-(4-chlorobenzyl)-6-hydroxy-4-phenylazepane-4-carbonitrile 27, was isolated in pure form by means of column chromatography on silica gel (hexane/EtOAc 1/1).

Alternative procedure: To a solution of trans-1-(4-chlorobenzyl)-2-chloromethyl-4-phenylpiperidine4-carbonitrile 11c $(0.95 \mathrm{mmol})$ in ethanol $(10 \mathrm{ml})$, sodium acetate $(1.9 \mathrm{mmol}, 2$ equiv) was added and the resulting solution was placed in a $80 \mathrm{ml}$ sealed glass vessel, provided with an appropriate stirring bar and subjected to microwave conditions $\left(110^{\circ} \mathrm{C}, 20\right.$ minutes). Afterwards, the reaction mixture was poured into water $(10 \mathrm{ml})$ and extracted with $\mathrm{Et}_{2} \mathrm{O}(3 \times 10 \mathrm{ml})$. Drying $\left(\mathrm{MgSO}_{4}\right)$, filtration of the drying agent and evaporation of the solvent in vacuo afforded trans-6-acetoxy-1-(4-chlorobenzyl)-4phenylazepane-4-carbonitrile 25 and trans-2-acetoxymethyl-1-(4-chlorobenzyl)-4-phenylpiperidin-4carbonitrile 26 in a ratio of 71-79/21-29 (25/26). Subsequently, acetates 25 and 26 were redissolved in $\mathrm{MeOH}$, after which lithium hydroxide (1.3 mmol, 2 equiv) was added and the resulting solution was heated under reflux for 1 hour. Afterwards, the reaction mixture was poured into water (10 ml) and extracted with $\mathrm{Et}_{2} \mathrm{O}(3 \times 10 \mathrm{ml})$. Drying $\left(\mathrm{MgSO}_{4}\right)$, filtration of the drying agent and evaporation of 
the solvent in vacuo afforded a mixture of trans-1-(4-chlorobenzyl)-6-hydroxy-4-phenylazepane-4carbonitrile 27 and trans-1-(4-chlorobenzyl)-2-hydroxymethyl-4-phenylpiperidin-4-carbonitrile 28 in a ratio of 71-79/21-29 (27/28). The major constituent, trans-1-(4-chlorobenzyl)-6-hydroxy-4phenylazepane-4-carbonitrile $\mathbf{2 7}$, was isolated in pure form by means of column chromatography on silica gel (hexane/EtOAc 1/1).trans-1-(4-Chlorobenzyl)-6-hydroxy-4-phenylazepane-4-carbonitrile 27. $(55 \%)$ Yellow oil. $R_{\mathrm{f}}=0.29$ (hexane/EtOAc 3/1). ${ }^{1} \mathrm{H}$ NMR $\left(\mathrm{CDCl}_{3}\right): \delta$ 2.02-2.07 $(2 \mathrm{H}, \mathrm{m}) ; 2.15-2.40$ $(2 \mathrm{H}, \mathrm{m}) ; 2.41(1 \mathrm{H}, \mathrm{dd}, J=14.3,5.0,1.1 \mathrm{~Hz}) ; 2.83-2.91(3 \mathrm{H}, \mathrm{m}) ; 3.01(1 \mathrm{H}, \mathrm{dd}, J=13.2,3.3 \mathrm{~Hz}) ; 3.65(1 \mathrm{H}$, $\mathrm{d}, J=13.5 \mathrm{~Hz}) ; 3.71(1 \mathrm{H}, \mathrm{d}, J=13.5 \mathrm{~Hz}) ; 4.06-4.17(1 \mathrm{H}, \mathrm{m}) ; 7.24-7.51(9 \mathrm{H}, \mathrm{m}) .{ }^{13} \mathrm{C} \mathrm{NMR}\left(\mathrm{CDCl}_{3}\right) ; \delta 40.7$ $\left(\mathrm{CH}_{2}\right) ; 43.6(\mathrm{C}) ; 47.7\left(\mathrm{CH}_{2}\right) ; 52.8\left(\mathrm{CH}_{2}\right) ; 59.8\left(\mathrm{CH}_{2}\right) ; 62.6\left(\mathrm{CH}_{2}\right) ; 68.3(\mathrm{CH}) ; 122.6(\mathrm{C}) ; 125.2(\mathrm{CH}) ; 127.9$ $(\mathrm{CH}) ; 128.7(\mathrm{CH}) ; 129.2(\mathrm{CH}) ; 130.4(\mathrm{CH}) ; 133.1(\mathrm{C}) ; 137.5(\mathrm{C}) ; 142.6(\mathrm{C}) . \mathrm{IR}\left(\mathrm{cm}^{-1}\right): \mathrm{v}_{\mathrm{OH}}=3422 \mathrm{v}_{\mathrm{CN}}=$ 2236. $\mathrm{MS}(70 \mathrm{eV}): \mathrm{m} / \mathrm{z}(\%): 341 / 3\left(\mathrm{M}^{+}+1,100\right)$. Anal. Calcd for $\mathrm{C}_{20} \mathrm{H}_{21} \mathrm{ClN}_{2} \mathrm{O}: \mathrm{C} 70.48 ; \mathrm{H} 6.21 ; \mathrm{N}$ 8.22. Found: C 70.74; H 6.49; N 8.08.

trans-1-(4-Chlorobenzyl)-2-hydroxymethyl-4-phenylpiperidine-4-carbonitrile 28. Spectral data derived from a mixture of nitriles 27 and 28. Yellow oil. $R_{\mathrm{f}}=0.16$ (hexane/EtOAc 9/1). ${ }^{1} \mathrm{H}$ NMR $\left(\mathrm{CDCl}_{3}\right): \delta 1.92-2.10(2 \mathrm{H}, \mathrm{m}) ; 2.36(2 \mathrm{H}, \mathrm{d}, J=5.0 \mathrm{~Hz}) ; 2.55(1 \mathrm{H}, \mathrm{dt}, J=11.7,4.0 \mathrm{~Hz}) ; 2.78-3.01(2 \mathrm{H}, \mathrm{m})$; $3.16(1 \mathrm{H}, \mathrm{d}, J=13.8 \mathrm{~Hz}) ; 3.51(1 \mathrm{H}, \mathrm{d}($ broad),$J=11.0 \mathrm{~Hz}) ; 3.98(1 \mathrm{H}, \mathrm{dd}, J=11.0,3.3 \mathrm{~Hz}) ; 4.17(1 \mathrm{H}, \mathrm{d}, J$ $=13.8 \mathrm{~Hz}) ; 7.23-7.49(9 \mathrm{H}, \mathrm{m}) .{ }^{13} \mathrm{C} \operatorname{NMR}\left(\mathrm{CDCl}_{3}\right) ; \delta 35.7\left(\mathrm{CH}_{2}\right) ; 39.8\left(\mathrm{CH}_{2}\right) ; 43.0(\mathrm{C}) ; 49.6\left(\mathrm{CH}_{2}\right) ; 57.0$ $\left(\mathrm{CH}_{2}\right) ; 60.0(\mathrm{CH}) ; 62.9\left(\mathrm{CH}_{2}\right) ; 122.2(\mathrm{C}) ; 125.6(\mathrm{CH}) ; 128.4(\mathrm{CH}) ; 128.8(\mathrm{CH}) ; 129.2(\mathrm{CH}) ; 130.3(\mathrm{CH})$; 133.1 (C); 137.0 (C); 139.9 (C). IR $\left(\mathrm{cm}^{-1}\right): \mathrm{v}_{\mathrm{OH}}=3423 \mathrm{v}_{\mathrm{CN}}=2234 . \mathrm{MS}(70 \mathrm{eV}): \mathrm{m} / \mathrm{z}(\%): 341 / 3\left(\mathrm{M}^{+}+1,100\right)$.

Synthesis of 2-arylmethyl-5-phenyl-2,7-diazabicyclo[3.3.1]nonanes 29. As a representative example, the synthesis of 2-(4-methylbenzyl)-5-phenyl-2,7-diazabicyclo[3.3.1]nonane $\mathbf{2 9 b}$ is described here. To a solution of cis-1-(4-methylbenzyl)-2-chloromethyl-4-phenylpiperidine-4-carbonitrile 9 b (0.6 mmol) in dry THF (10 ml), $\mathrm{LiAlH}_{4}(1.2 \mathrm{mmol}, 2$ equiv) was added and the resulting solution was heated under reflux for 2 hours under nitrogen atmosphere. The reaction mixture was poured into water (10 $\mathrm{ml})$ and extracted with $\mathrm{Et}_{2} \mathrm{O}(3 \times 10 \mathrm{ml})$. Drying $\left(\mathrm{MgSO}_{4}\right)$, filtration of the drying agent, and evaporation of 
the solvent in vacuo afforded 2-(4-methylbenzyl)-5-phenyl-2,7-diazabicyclo[3.3.1]nonane 29b, which

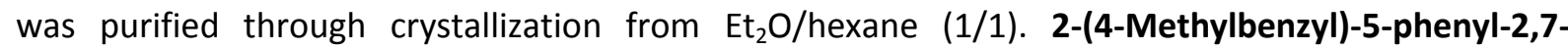
diazabicyclo[3.3.1]nonane 29b. (75\%) White Crystals. $\mathrm{Mp}=110.3^{\circ} \mathrm{C} .{ }^{1} \mathrm{H}$ NMR $\left(\mathrm{CDCl}_{3}\right): \delta$ 1.92-2.03 $(2 \mathrm{H}, \mathrm{m}) ; 2.13-2.27(2 \mathrm{H}, \mathrm{m}) ; 2.34(3 \mathrm{H}, \mathrm{s}) ; 2.65(1 \mathrm{H}, \mathrm{dd}, J=12.9,1.9 \mathrm{~Hz}) ; 2.80-2.90(3 \mathrm{H}, \mathrm{m}) ; 3.27(1 \mathrm{H}, \mathrm{dd}$, $J=12.7,2.8 \mathrm{~Hz}) ; 3.39-3.49(2 \mathrm{H}, \mathrm{m}) ; 3.73(1 \mathrm{H}, \mathrm{d}, J=13.2 \mathrm{~Hz}) ; 3.78(1 \mathrm{H}, \mathrm{d}, J=13.2 \mathrm{~Hz}) ; 7.11-7.36(9 \mathrm{H}$, m). ${ }^{13} \mathrm{C} \mathrm{NMR}\left(\mathrm{CDCl}_{3}\right) ; \delta 21.3\left(\mathrm{CH}_{3}\right) ; 35.4(\mathrm{C}) ; 37.1\left(\mathrm{CH}_{2}\right) ; 37.4\left(\mathrm{CH}_{2}\right) ; 46.4\left(\mathrm{CH}_{2}\right) ; 49.7\left(\mathrm{CH}_{2}\right) ; 52.1(\mathrm{CH})$; $58.7\left(\mathrm{CH}_{2}\right) ; 60.0\left(\mathrm{CH}_{2}\right) ; 125.1(\mathrm{CH}) ; 126.1(\mathrm{CH}) ; 128.4(\mathrm{CH}) ; 128.9(\mathrm{CH}) ; 129.1(\mathrm{CH}) ; 136.5(\mathrm{C}) ; 136.6(\mathrm{C}) ;$ 149.2 (C). IR $\left(\mathrm{cm}^{-1}\right): v_{\mathrm{NH} 2}=3336$. MS (70 eV): $\mathrm{m} / \mathrm{z}(\%): 307\left(\mathrm{M}^{+}+1,100\right)$. Anal. Calcd for $\mathrm{C}_{21} \mathrm{H}_{26} \mathrm{~N}_{2}: \mathrm{C}$ 82.31; H 8.55; N 9.14. Found: C 82.39; H 8.63; N 9.02.

Synthesis of tert-butyl 2-(4-methylbenzyl)-5-phenyl-2,7-diazabicyclo[3.3.1]nonane-7-carboxylate 30. To a solution of 2-(4-methylbenzyl)-5-phenyl-2,7-diazabicyclo[3.3.1]nonane $29 \mathrm{~b}(0.2 \mathrm{mmol})$ in dry $\mathrm{CH}_{2} \mathrm{Cl}_{2}(10 \mathrm{ml}), \mathrm{Boc}_{2} \mathrm{O}(0.22 \mathrm{mmol}, 1.1$ equiv), pyridine $(0.22 \mathrm{mmol}, 1.1$ equiv) and DMAP (0.022 mmol, 0.1 equiv) were added, and the resulting solution was stirred at room temperature for 3 hours. The reaction mixture was poured into brine $(10 \mathrm{ml})$ and extracted with $\mathrm{CH}_{2} \mathrm{Cl}_{2}(3 \times 10 \mathrm{ml})$. Drying $\left(\mathrm{MgSO}_{4}\right)$, filtration of the drying agent and evaporation of the solvent in vacuo afforded tertbutyl 2-(4-methylbenzyl)-5-phenyl-2,7-diazabicyclo[3.3.1]nonane-7-carboxylate 30, which was isolated in pure form by means of column chromatography on silica gel (hexane/EtOAc 3/1). tertButyl 2-(4-methylbenzyl)-5-phenyl-2,7-diazabicyclo[3.3.1]nonane-7-carboxylate 30. (90\%) Yellow oil. ${ }^{1} \mathrm{H}$ NMR $\left(\mathrm{CDCl}_{3}\right): \delta 1.57(9 \mathrm{H}, \mathrm{s}) ; 1.82-2.03(2 \mathrm{H}, \mathrm{m}) ; 2.11-2.25(2 \mathrm{H}, \mathrm{m}) ; 2.33(3 \mathrm{H}, \mathrm{s}) ; 2.63-2.81(3 \mathrm{H}$, m); 2.96-3.07 (2H, m); $3.75(2 \mathrm{H}, 2 \times d, J=14.3 \mathrm{~Hz}) ; 4.55(2 \mathrm{H}, \mathrm{d}, J=13.2 \mathrm{~Hz}) ; 7.12-7.38(9 \mathrm{H}, \mathrm{m}) .{ }^{13} \mathrm{C} \mathrm{NMR}$ $\left(\mathrm{CDCl}_{3}\right) ; \delta 21.2\left(\mathrm{CH}_{3}\right) ; 28.9\left(\mathrm{CH}_{3}\right) ; 35.5(\mathrm{C}) ; 37.0\left(\mathrm{CH}_{2}\right) ; 38.0\left(\mathrm{CH}_{2}\right) ; 42.8\left(\mathrm{CH}_{2}\right) ; 48.1\left(\mathrm{CH}_{2}\right) ; 50.8(\mathrm{CH}) ; 53.2$ $\left(\mathrm{CH}_{2}\right) ; 60.0\left(\mathrm{CH}_{2}\right) ; 79.8(\mathrm{C}) ; 125.2(\mathrm{CH}) ; 126.6(\mathrm{CH}) ; 128.6(\mathrm{CH}) ; 128.8(\mathrm{CH}) ; 129.2(\mathrm{CH}) ; 136.0(\mathrm{C}) ; 136.7$ (C); 147.4 (C); 154.3 (C). IR $\left(\mathrm{cm}^{-1}\right): v_{C O}=1687 . \mathrm{MS}(70 \mathrm{eV}): \mathrm{m} / \mathrm{z}(\%): 407\left(\mathrm{M}^{+}+1,100\right)$. Anal. Calcd for $\mathrm{C}_{26} \mathrm{H}_{34} \mathrm{~N}_{2} \mathrm{O}_{2}$ : C 76.81; $\mathrm{H} 8.43 ; \mathrm{N}$ 6.89. Found: C 77.06; $\mathrm{H} 8.71 ; \mathrm{N} 6.98$. 
representative example, the synthesis of trans-4-aminomethyl-2-methyl-1-(4-methylbenzyl)-4phenylpiperidine 31b is described here. To a solution of trans-2-chloromethyl-1-(4-methylbenzyl)-4phenylpiperidine-4-carbonitrile $\mathbf{1 1 b}(0.6 \mathrm{mmol})$ in dry THF (10 ml), $\mathrm{LiAlH}_{4}(1.2 \mathrm{mmol}, 2$ equiv) was added and the resulting solution was heated under reflux for 2 hours under nitrogen atmosphere. The reaction mixture was poured into water $(10 \mathrm{ml})$ and extracted with $\mathrm{Et}_{2} \mathrm{O}(3 \times 10 \mathrm{ml})$. Drying $\left(\mathrm{MgSO}_{4}\right)$, filtration of the drying agent and evaporation of the solvent afforded trans-4-aminomethyl2-methyl-1-(4-methylbenzyl)-4-phenylpiperidine 31b, which was isolated in pure form by means of column chromatography on silica gel $\left(\mathrm{CH}_{2} \mathrm{Cl}_{2} / \mathrm{MeOH}\right.$ 94/6). trans-4-Aminomethyl-2-methyl-1-(4methylbenzyl)-4-phenylpiperidine 31b. (65\%) Yellow oil. $R_{\mathrm{f}}=0.06\left(\mathrm{CH}_{2} \mathrm{Cl}_{2} / \mathrm{MeOH} 94 / 6\right) .{ }^{1} \mathrm{H} \mathrm{NMR}$ $\left(\mathrm{CDCl}_{3}\right): \delta 1.23(1 \mathrm{H}, \mathrm{d}, J=6.1 \mathrm{~Hz}) ; 1.67(1 \mathrm{H}, \mathrm{dd}, J=13.2,11.6 \mathrm{~Hz}) ; 1.81(1 \mathrm{H}, \mathrm{dt}, J=13.1,3.8 \mathrm{~Hz}) ; 2.00$ $(1 \mathrm{H}, \mathrm{dd}, J=13.2,2.8 \mathrm{~Hz}) ; 2.07(1 \mathrm{H}, \mathrm{dt}, J=13.1,2.5 \mathrm{~Hz}) ; 2.24(1 \mathrm{H}, \mathrm{dt}, J=12.1,2.5 \mathrm{~Hz}) ; 2.33(3 \mathrm{H}, \mathrm{s})$; 2.54-2.60 $(1 \mathrm{H}, \mathrm{m}) ; 2.75(1 \mathrm{H}, \mathrm{dt}, J=12.1,3.8 \mathrm{~Hz}) ; 2.92$ and $2.98(2 \mathrm{H}, 2 \times \mathrm{d}, J=12.9 \mathrm{~Hz}) ; 3.17(2 \mathrm{H}, \mathrm{d}, J=$ 13.2 Hz); $4.08(2 \mathrm{H}, \mathrm{d}, J=13.2 \mathrm{~Hz}) ; 7.10-7.34(9 \mathrm{H}, \mathrm{m}) .{ }^{13} \mathrm{C} \mathrm{NMR}\left(\mathrm{CDCl}_{3}\right) ; \delta 21.2\left(\mathrm{CH}_{3}\right) ; 21.6\left(\mathrm{CH}_{3}\right) ; 32.3$ $\left(\mathrm{CH}_{2}\right) ; 41.0(\mathrm{C}) ; 42.6\left(\mathrm{CH}_{2}\right) ; 47.5\left(\mathrm{CH}_{2}\right) ; 48.2\left(\mathrm{CH}_{2}\right) ; 52.5(\mathrm{CH}) ; 57.8\left(\mathrm{CH}_{2}\right) ; 125.9(\mathrm{CH}) ; 126.1(\mathrm{CH}) ; 128.4$ (CH); 129.0 (CH); 129.2 (CH); 135.9 (C); 136.5 (C); 147.6 (C). IR ( $\left.\mathrm{cm}^{-1}\right): \mathrm{v}_{\mathrm{NH} 2}=3370 . \mathrm{MS}(70 \mathrm{eV}): \mathrm{m} / \mathrm{z}$ (\%): $309\left(\mathrm{M}^{+}+1,100\right)$. Anal. Calcd for $\mathrm{C}_{21} \mathrm{H}_{28} \mathrm{~N}_{2}$ : C 81.77; H 9.15; N 9.08. Found: C 81.95; H 9.32; N 8.98.

\section{Acknowledgements}

The authors are indebted to the "Institute for the Promotion of Innovation through Science and Technology - Flanders" (IWT-Vlaanderen), to the "Fund for Scientific Research - Flanders" (FWOVlaanderen) and to Ghent University (GOA) for financial support.

Supporting Information Available: Spectroscopic data of compounds $6 b, c, 7 b, c, 9 b, c$, 11b,c, 21a, 22a, 29a,c and 31a. This material is available free of charge via the Internet at http://pubs.acs.org. 


\section{References}

\footnotetext{
${ }^{1}$ Watson, P.S.; Jiang, B.; Scott, B. Org. Biomol. Chem. 2000, 2, 3679.
}

${ }^{2}$ (a) Buffat, M.G.P. Tetrahedron 2004, 60, 1701. (b) Weintraub, P.M.; Sabol, J.S.; Kane, J.M.; Borcherding, D.R. Tetrahedron 2003, 59, 2953. (c) Bailey, P.D.; Millwood, P.A.; Smith, P.D. Chem Commun. 1998, 633. (d) Mitchinson, A.; Nadin, A. J. Chem. Soc., Perkin Trans. 1 2000, 2862.

${ }^{3}$ Källström, S.; Leino, R. Bioorg. Med. Chem. 2008, 16, 601.

${ }^{4}$ Macleod, A.M.; Stevenson, G.I. WO 94/13639, 1994. CAN 121:205217.

${ }^{5}$ Bock, M.G.; Patane, M.A.; Ponticello, R.A. WO 9717967, 1997. CAN 127:65787.

${ }^{6}$ (a) Vila, X.; Zard, S.Z. Heterocycles 2006, 70, 45. (b) Targum, S.; Zborowski, J.; Henry, M.; Schmitz, P.; Sebree, T.; Wallin, B. Eur. Neuropsychopharmacol. 1995, 5, 4.(c) Janssen, P.A.J.; Niemegeers, C.J.E.; Schellekens, K.H.L. Arzneim Forsch. 1959, 9, 765.

${ }^{7}(a)$ Kokotos, C.G.; Aggerwal, V.K. Org. Lett. 2007, 9, 2099. (b) Delarue-Cochin, S.; McCortTranchepain, I. Org. Biomol. Chem. 2009, 7, 706.

${ }^{8}$ (a) Bisai, A.; Singh, V.K. Tetrahedron Lett. 2007, 48, 1907. (b) Mumford, P.M.; Tarver, G.J.; Shipman, M. J. Org. Chem. 2009, 74, 3573.

${ }^{9}$ (a) Harrity, J.P.A.; Provoost, O. Org. Biomol. Chem. 2005, 3, 1349. (b) Hedley, S.J.; Moran, W.J.; Prenzl, A.H.G.P.; Price, D.A.; Harrity, J.P.A. Synlett 2001, 1596.

${ }^{10}$ Ahman, J. Somfai, P. J. Am. Chem. Soc. 1994, 116, 9781.

${ }^{11}$ (a) Broeckx, W.; Overbergh, N.; Samyn, C.; Smets, G.; L'Abbe, G. Tetrahedron 1971, 27, 3527. (b) Nayak, S.K.; Lambertus, T.; Zwanenburg, B. Tetrahedron Lett. 1999, 40, 981.

${ }^{12}$ (a) D’hooghe, M.; Vervisch, K.; De Kimpe, N. J. Org. Chem. 2007, 72, 7329. (b) Vervisch, K.; D’hooghe, M.; Törnroos, K.W.; De Kimpe, N. Org. Biomol. Chem. 2009, 7, 3271. 
${ }^{13}(a)$ D'hooghe, M.; Mangelinckx, S.; Persyn, E.; Van Brabandt, W.; De Kimpe, N. J. Org. Chem. 2006, 71, 4232 (b) D’hooghe, M.; Vervisch,K.; Van Nieuwenhove, A.; De Kimpe, N. Tetrahedron Lett.. 2007, $48,1771$.

${ }^{14}$ (a) De Kimpe, N.; Jolie, R.; De Smaele, D. J. Chem. Soc., Chem. Commun. 1994, 1221. (b) De Kimpe, N.; De Smaele, D.; Szakonyi, Z. J. Org. Chem. 1997, 62, 2448. (c) D’hooghe, M.; Waterinckx, A.; De Kimpe, N. J. Org. Chem. 2005, 70, 227. (d) D’hooghe, M.; Rottiers, M.; Jolie, R.; De Kimpe, N. Synlett 2005, 931.

${ }^{15}$ (a) D'hooghe, M.; Rottiers, M.; Kerkaert, I.; De Kimpe, N. Tetrahedron 2005, 61, 8746. (b) D'hooghe, M.; Kerkaert, I.; Rottiers, M.; De Kimpe, N. Tetrahedron 2004, 60, 3637. (c) D'hooghe, M.; Waterinckx, A.; Vanlangendonck, T.; De Kimpe, N. Tetrahedron 2006, 62, 2295. (d) D’hooghe, M.; De Kimpe, N. Arkivoc 2008, (ix), 6.

${ }^{16}$ (a) Tang, F.Y.; Qu, L.Q.; Xu, Y.; Ma, R.J.; Chen, S.H.; Li, G. Synth. Commun. 2007, 37, 3793. (b) Burk, R.M.; Overman, L.E. Heterocycles, 1993, 35, 205. (c) Cheng, C.Y.; Lu, H.Y. Lee, F.M. Eur. J. Med. Chem. 1991, 26, 125. (d) Cheng, C.Y.; Lu, H.Y. Lee, F.M.; Tam, S.W. J. Pharm. Sciences 1990, $79,758$.

${ }^{17}$ (a) D'hooghe, M.; Van Brabandt, W.; De Kimpe, N. J. Org. Chem. 2004, 69, 2703. (b) D'hooghe, M.; Van Speybroeck, V.; Waroquier, M.; De Kimpe, N. Chem. Commun. 2006, 1554. (c) D’hooghe, M.; De Kimpe, N. Synlett 2006, 2089.

${ }^{18}$ (a) Juaristi. E.; Soloshonok, V. In Enantioselective Synthesis of B-Amino Acids, Wiley, New Jersey, 2005: Vol. 2, p 634. (b) Fulöp, F.; Martinek, T. A.; Toth, G. K. Chem. Soc. Rev. 2006, 35, 323. (c) Fulöp, F. Chem. Rev.2001, 101, 2181.

${ }^{19}$ (a) Felluga, F.; Gombac, V.; Pitacco, G.; Valentin, E. Tetrahedron: Asymm. 2005, 16, 1341. (b) Goka, V. N.; Stenbol, T. B.; Krogsgaard-Larsen, P.; Schlewer, G. Eur. J. Med. Chem. 2004, 39, 889. (c) Krogsgaard-Larsen, P.; Scheel-Kruger, J.; Kofold, H. GABA-Neurotransmitters: Pharmacochemical, Biochemical and pharcological aspects, Munksgaard, Copenhagen, 1979, p 552. 
${ }^{20}$ (a) Leemans, E.; D’hooghe, M; Dejaegher, Y.; Törnroos, K.; De Kimpe, N. Eur. J. Org. Chem. 2010, 352. (b) Mangelinckx, S.; D’hooghe, M.; Peeters, S.; De Kimpe, N. Synthesis 2009, 1105. (c) Mangelinckx, S.; Žukauskaitė, A.; Buinauskaitè, V.; Šačkus, A.; De Kimpe, N. Tetrahedron Lett. 2008, 49, 6896. (d) Kiss, L.; Mangelinckx, S.; Fülöp, F.; De Kimpe, N. Org. Lett. 2007, 9, 4399. (e) Giubellina, N.; Mangelinckx, S.; Törnroos, K.W.; De Kimpe, N. J. Org. Chem. 2006, 71, 5881. (f) Mangelinckx, S.; De Kimpe, N. Synlett, 2005, 1521. (g) Colpaert, F; Mangelinckx, S.; De Kimpe, N Org. Lett. 2010, 12, 1904.

${ }^{21}$ (a) H. Groger, Chem. Rev., 2003, 103, 2795. (b) D. Enders, J. P. Shilvock, Chem. Soc. Rev., 2000, 29, 359. (b) Blanco-Ania, D.; Valderas-Cortina; C. Hermkens, P.H.H.; Sliedregt, L.A.J.M.; Scheeren, H.W.; Rutjes, F.P.J.T. Molecules 2010, 15, 2269. (c) Vink, M.K.S.; Schortinghuis, C.A.; Luten, J.; van Maarseveen, J.H.; Schoemaker, H.E.; Hiemstra, H.; Rutjes, F.P.J.T. J. Org. Chem. 2002, 67, 7869. (d) Vink, M.K.S.; Wijtmans, R.; Reisinger, C.; Van den Berg, R.J.F.; Schortinghuis, C.A.; Schwab, H.; Schoemaker, H.E.; Hiemstra, H.; Rutjes, F.P.J.T. biotechnol. J. 2006, 1, 569-573.

${ }^{22}$ (a) Harker, E.A.; Daniels, D.S.; Guarracino, D.A.; Schepartz, A. Bioorg. Med. Chem. 2009, 17, 2038. (b) Bautista, A.D.; Appelbaum, J.S.; Craig, C.J.; Michel, J.; Schepartz, A. J. Am. Chem. Soc. 2010, 132, 2904.

${ }^{23}$ Catak, S.; D’hooghe, M.; De Kimpe, N.; Waroquier, M.; Van Speybroeck, V. J. Org. Chem. 2010, 75, 885.

${ }^{24}$ (a) Olofsson, B.; Somfai, P. J. Org. Chem. 2002, 67, 8574. (b) Kobayashi, S.; Ishitani, H.; Ueno, M. J. Am. Chem. Soc. 1998, 120, 431. (c) Castejon, P.; Moyano, A.; Pericas, M. A.; Riera, A. Tetrahedron 1996, 52, 7063.

${ }^{25}$ (a) Reddy, L.R.; Reddy, M.A.; Bhanumathi, N.; Rao, K. R. New J. Chem. 2001, 25, 221. (b) Rodriguez, J.R.; Navarro, A. Tetrahedron Lett. 2004, 45, 7495.

${ }^{26}$ (a) Sundararajan, G.; Vijayakrishn, K.; Vargheseb, B. Tetrahedron Lett. 2004, 45, 8253. (b) Ager, D.J.; Prakash, I.; Schaad, D.R. Chem. Rev. 1996, 96, 835. (c) Chakraborti, A.K.; Kondaskar, A. Tetrahedron Lett.2003, 44, 8315. 
${ }^{27}$ (a) Chong, H.-S.; Garmestani, K.; Bryant, H.L., Jr.; Brechbiel, M.W. J. Chem. Soc., Perkin Trans. 1 2002, 2080. (b) Chong, H.-S.; Garmestani, K.; Bryant, H.L., Jr.; Brechbiel, M.W. J. Org. Chem. 2001, 66, 7745. (c) Berkes, D.; Decroix, B. B. Soc. Chim. Fr. 1994, 131, 986. (d) Morie, T.; Kato, S.; Harada, H.; Fujiwara, I.; Watanabe, K.; Matsumoto, J. J. Chem. Soc., Perkin Trans. 1 1994, 2565..

${ }^{28}$ Leeson, P.D.; Williams, B. J.; Rowley, M.; Moore, K.W.; Baker, R.;,Kemp, J.A.; Priestley T.; Foster, A.C.;Donald, A.E. Biorg. Med. Chem. Lett. 1993, 3, 71.

${ }^{29}$ (a) Hashimoto, A.; Jacobson, A.E.; Rothman, R.B.; Dersch, C.G.; Flippen-Anderson, J.L.; Rice, K.C. Bioorg. Med. Chem. 2002, 10, 3319. (b) Kim, I.J.; Dersch, C.G.; Rothman, R.B.; Jacobson, A.E.; Rice, K.C. Bioorg. Med. Chem. 2004, 12, 4543. (c) Li, W.; Wang, X-H.; Lau, C-W; Tang, Y.; Xie, Q.; Qui, Z-B. Acta Pharm. Sin. 2006, 27, 1247.

${ }^{30}$ (a) Welder, C.O.; Ashby, E.C. J. Org. Chem. 1997, 62, 4829. (b) D'hooghe, M.; Dekeukeleire, S.; De Kimpe, N. Org. Biomol. Chem. 2008, 6, 1190.

${ }^{31}$ Bryans, J.S.; Horwell, D.C.; Kneen, C.O.; Wustrow, D. WO 99/31057, 1999. CAN 131:44829 